\title{
1995 Building Energy Codes and Standards Workshops: Summary and Documentation
}
L. J. Sandahl
D. L. Shankle

February 1996

Prepared for the U.S. Department of Energy under Contract DE-AC06-76RLO 1830

Pacific Northwest National Laboratory Operated for the U.S. Department of Energy by Battelle 


\title{
DISCLAIMER
}

This report was prepared as an account of work sponsored by an agency of the United States Government. Neither the United States Government nor any agency thereof, nor Battelle Memorial Institute, nor any of their employees, makes any warranty, express or implied, or assumes any legal liability or responsibility for the accuracy, completeness, or usefulness of any information, apparatus, product, or process disclosed, or represents that its use would not infringe privately owned rights. Reference herein to any specific commercial product, process, or service by trade name, trademark, manufacturer, or otherwise does not necessarily constitute or imply its endorsement, recommendation, or favoring by the United States Government or any agency thereof, or Battelle Memorial Institute. The views and opinions of authors expressed herein do not necessarily state or reflect those of the United States Government or any agency thereof.

\author{
PACIFIC NORTHWEST NATIONAL LABORATORY \\ operated by \\ BATTELLE \\ for the \\ UNITED STATES DEPARTMENT OF ENERGY \\ under Contract DE-ACO6-76RLO 1830
}

Printed in the United States of America

Available to DOE and DOE contractors from the

Office of Scientific and Technical Information, P.O. Box 62, Oak Ridge, TN 37831: prices available from (615) 576-8401.

Available to the public from the National Technical Information Service, U.S. Department of Commerce, 5285 Port Royal Rd., Springfield, VA 22161 


\section{DISCLAIMER}

Portions of this document may be illegible electronic image products. Images are produced from the best available original document. 


\title{
1995 Building Energy Codes and Standards Workshops: Summary and Documentation
}

\author{
L.J. Sandahl \\ D.L. Shankle
}

February 1996

Prepared for

the U.S. Department of Energy

under Contract DE-AC06-76RLO 1830

Pacific Northwest National Laboratory

Richland, Washington 99352 


\section{Foreword}


During the spring of 1995, Pacific Northwest National Laboratory (PNNL), on behalf of the U.S. Department of Energy (DOE) Office of Codes and Standards, conducted four two-day Regional Building Energy Codes and Standards workshops across the United States. Workshops were held in Chicago, Denver, Rhode Island, and Atlanta.

The workshops were designed to benefit state-level officials including staff of building code commissions, energy offices, public utility commissions, and others involved with adopting/updating, implementing, and enforcing building energy codes in their states.

The workshops provided an opportunity for state and other officials to learn more about residential and commercial building energy codes and standards, the role of the U.S. Department of Energy and the Building Standards and Guidelines Program at Pacific Northwest National Laboratory, Home Energy Rating Systems (HERS), Energy Efficient Mortgages (EEM), training issues, and other topics related to the development, adoption, implementation, and enforcement of building energy codes. Participants heard success stories, got tips on enforcement training, and received technical support materials.

In addition to receiving information on the above topics, workshop participants had an opportunity to provide input on code adoption issues, building industry training issues, building design issues, and exemplary programs across the United States.

This paper documents the workshop planning, findings, and follow-up processes. 


\section{Contents}

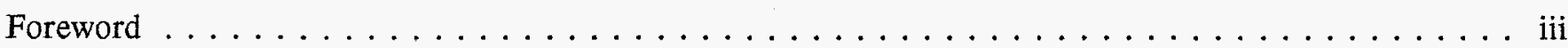

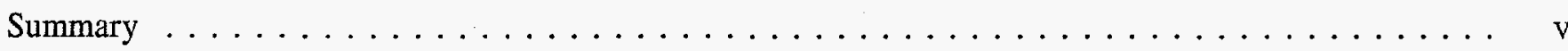

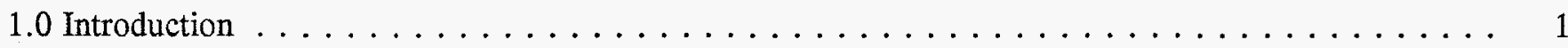

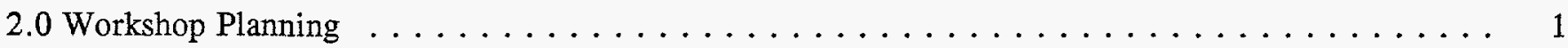

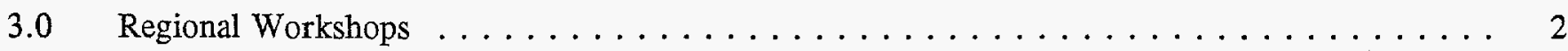

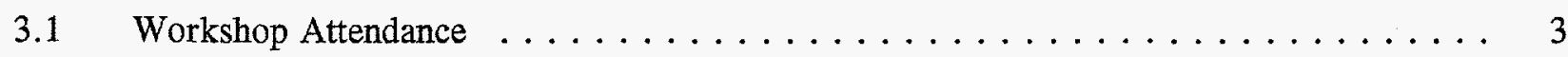

3.2 Workshop Agendas $\ldots \ldots \ldots \ldots \ldots \ldots \ldots \ldots \ldots \ldots \ldots \ldots \ldots \ldots \ldots$

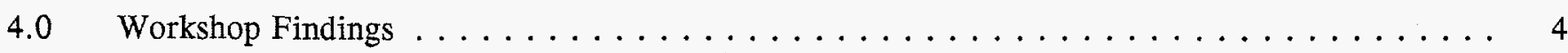

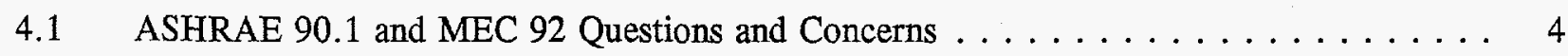

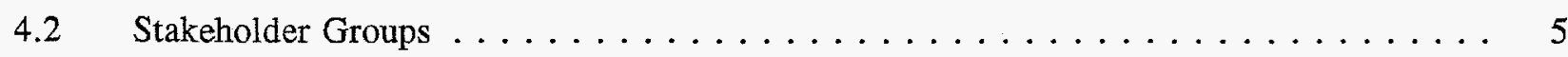

$4.3 \quad$ Potential Building Energy Code Implementation Partners $\ldots \ldots \ldots \ldots \ldots \ldots$

4.4 Building Energy Code Training and Technical Assistance Currently Available . . . . . . . 7

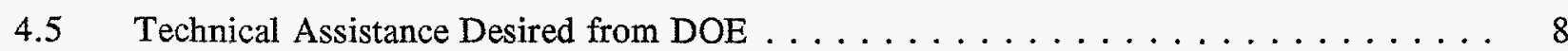

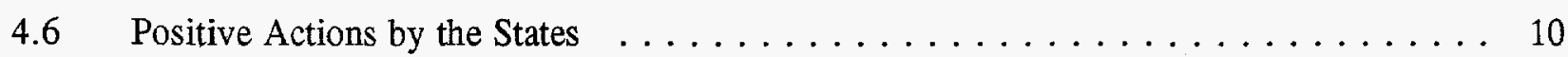

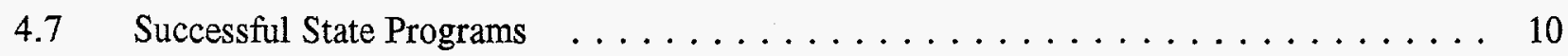

4.8 "Words of Advice" from Workshop Participants $\ldots \ldots \ldots \ldots \ldots \ldots \ldots \ldots$

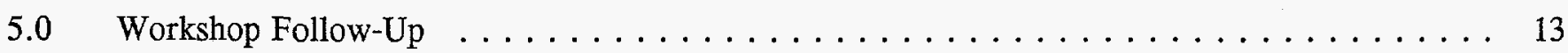

Appendix A - States Included in the DOE Support Office Regions $\ldots \ldots \ldots \ldots \ldots \ldots \ldots$

Appendix B - Regional Building Energy Codes and Standards Workshop Questionnaire Responses . . . . 16

Appendix C - Workshop Evaluation Comments $\ldots \ldots \ldots \ldots \ldots \ldots \ldots \ldots \ldots \ldots \ldots \ldots$

\section{Tables}

11994 Regional Building Energy Codes and Standards Workshop Dates and Locations . . . . . . . . 3 


\subsection{Introduction}

\subsection{Workshop Planning}

The Pacific Northwest National Laboratory, on behalf of the U.S. Department of Energy (DOE) Office of Codes and Standards, conducted four two-day Regional Building Energy Codes and Standards workshops across the United States during June of 1995. The workshops were facilitated by staff of the Building Standards and Guidelines Program, which Pacific Northwest National Laboratory manages for DOE. Field staff at DOE's Regional Support Offices assisted with the workshops. Workshops were held in the following cities:

- Chicago, Illinois, June 1-2, 1995

- Denver, Colorado, June 19-20, 1995.

- $\quad$ Lincoln, Rhode Island, June 22-23, 1995

- $\quad$ Atlanta, Georgia, June 27-28, 1995

This report documents the workshop planning, findings, and follow-up processes. Section 2 describes the workshop planning process, the process used to identify and reach potential workshop participants, and the goals of the workshops. Section 3 presents workshop dates, locations, workshop attendance, and agendas. Section 4 presents workshop findings. Section 5 describes workshop follow-up activities.

The regional workshops were an important component of Pacific Northwest National Laboratory's Building Standards and Guidelines Program implementation strategy in both 1994 and 1995. The goal of the implementation strategy is to disseminate information to the states and stakeholders and to provide materials and technical assistance to them.

The Laboratory facilitated DOE's first series of building energy code workshops in 1994. The primary goals of the 1995 workshops were to

- Provide an opportunity for states to discuss their specific issues and to share lessons learned and ideas for addressing building energy code-related challenges.

- Identify ways DOE can enhance training efforts already in place.

- Establish an infrastructure for launching new training programs on building energy codes.

- Allow key state officials the opportunity to network with and learn from their peers.

- Promote the adoption, implementation, and enforcement of building energy codes nationwide. 


\subsection{Regional Workshops}

- Determine how DOE can enhance energy code training efforts already in place and establish an infrastructure from which building energy codes and standards can be launched.

The approach taken to identify and reach state staff was to work with the DOE Regional Support Offices. The DOE Regional Support Offices are a critical link between DOE Headquarters and the 50 states. The Support Offices assisted Pacific Northwest National Laboratory with workshop planning and identifying key state officials and potential workshop speakers. A list of the states included in each DOE Support Office Region is presented in Appendix A.

Pacific Northwest National Laboratory initially worked with DOE to choose workshop locations. Each Support Office has an individual that has been designated as the lead for buildings-related work and research for the region. This person was typically the one responsible for coordinating with PNL. Appendix B lists a Support Office contact for each region.

In addition to working with the DOE Support Offices, Pacific Northwest National Laboratory used an internal database of state contacts based on the 1994 workshops to form its invitation list. The goal was to have at least one person from each state and U.S. protectorate attend a workshop.

Four Regional Building Energy Codes and Standards workshops were held as planned in the summer of 1995. Table 1 shows the workshop dates, locations, and DOE Support Office Regions invited. Support offices were grouped based on geographical region and the number of states included in each region.

Table 1. 1994 Regional Building Energy Codes and Standards Workshop Dates and Locations

\begin{tabular}{||c|c|c|c||}
\hline Date & City & $\begin{array}{c}\text { DOE } \\
\text { Regions }^{(a)}\end{array}$ & $\begin{array}{c}\text { Number } \\
\text { Attending }\end{array}$ \\
\hline \hline June 1-2,1995 & Chicago, IL & 5,7 & 28 \\
\hline June 19-20,1995 & Denver, CO & $8,9,10$ & 31 \\
\hline June 22-23, 1995 & Lincoln, RI & $1,2,3$ & 35 \\
\hline June 27-28, 1995 & Atlanta, GA & 4,6 & 67 \\
\hline $\begin{array}{l}\text { (a) See Appendix A for a list of the states included in each DOE } \\
\text { Support Office Region. }\end{array}$ \\
\hline
\end{tabular}




\subsection{Workshop Attendance}

\subsection{Workshop Agendas}

Representatives from 38 states and 2 territories attended the workshops. A total of 161 people, including DOE staff, attended the workshops: 28 people attended in Chicago, IL; 31 in Lincoln, RI; 35 in Denver, CO; and 67 in Atlanta, GA.

To identify relevant workshop topics for 1995, PNL workshop planners sent out a brief pre-workshop questionnaire to a cross-section of past participants listing possible topics and requesting suggestions for additional topics. The respondents showed an overwhelming interest in implementation and enforcement issues. HERS/EEMS was also seen as important, as were MEC implementation materials, building industry training, information on MEC and ASHRAE, and information on technical support materials. Other topics identified were an overview of the codes and standards process, development of local jurisdiction partnerships, the role of DOE in promoting building energy codes and standards, the status of codes in the states, and building design issues.

Each workshop began with a special address by the Director of the DOE Support Office in the region where the workshop was held. The agendas differed from last year's agendas by including much more input from state representatives. At each workshop, state energy office representatives from the region discussed their states' code programs and successful ways in which they had used DOE assistance to improve code implementation. The Energy Policy Act of 1992 (EPAct) was not the focal point it had been in the 1994 workshops. Also less background on DOE programs was given because many workshop participants had heard this. information at the 1994 workshops or from other sources. At each of the 1995 workshops, state representatives gave talks on the following topics:

- examples of technical assistance received

- code adoption issues in their state

- $\quad$ state program examples and discussion

- utility new construction programs and their linkage to codes

- $\quad$ experience with Home Energy Rating Systems.

At each workshop, a representative from DOE's Office of Codes and Standards presented the State Exemplary/Progressive/Developmental Program Awards results. DOE staff also gave presentations on the role of DOE in promoting building energy codes and standards. A representative of the Building Codes Assistance Project (BCAP) gave an overview of BCAP at each workshop. Staff from Pacific Northwest National Laboratory's Building Standards and Guidelines Program gave talks on the following topics: 
- overview of the Building Standards and Guidelines Program

- direct technical assistance

- Train-the-Trainer educational series overview

- $\quad$ MEC implementation materials (MECcheck)

- $\quad$ ASHRAE 90.1 implementation materials

Pacific Northwest National Laboratory staff also led discussions with state participants on energy code adoption, implementation, and enforcement issues.

The workshops were organized in a way that would encourage and facilitate discussion between participants, DOE, program staff, and state presenters. Most presentations were limited to 30 minutes or less to allow time for discussion and questions. Since attendance at the workshop was mainly limited to state staff responsible for the adoption, implementation, and enforcement of building energy codes in their state, discussions were typically of interest to most of the audience.

\subsection{Workshop Findings}

\subsection{ASHRAE 90.1 and MEC 92 Questions and Concerns}

A substantial amount of information on issues of concern to the states, state needs for technical assistance and tools, and information on stakeholder groups was collected at each workshop. To increase information collection, workshop questionnaires were distributed to participants prior to the workshop. Thirty-three participants completed and returned the pre-workshop questionnaire. Questionnaire responses are presented in Appendix B.

This section presents an overview of the information collected from workshop participants via the pre-workshop questionnaire and comments and questions stated during the workshops.

The Energy Policy Act of 1992 requires states to ensure that their commercial building codes meet or exceed the energy-efficiency requirements of the American Society of Heating, Refrigerating, and AirConditioning Engineers/llluminating Engineering Society (ASHRAE/IES) Standard 90.1 1989. It also requires states to review their residential building codes and encourages them to meet or exceed the Council of American Building Officials (CABO) Model Energy Code (MEC 1992). Participants had many concerns related to getting the codes implemented and enforced on a widespread basis in their states. A number of states mentioned that they are in need of funding to develop and implement building energy code training and enforcement programs.

Enforcement was the biggest concern among respondents. Education and training were also emphasized with respondents saying that stakeholders need to be informed of the energy code requirements and that code 
officials, builders, designers, etc., need to be trained to implement the new requirements. Several said that the codes were too complex and needed to be simplified. Lack of funding and lack of staff were mentioned as problems. A few thought that the CABO royalty was a barrier and some said the requirements were outdated, specifically that state codes should be structured to meet CABO's MEC '95 instead of the '92 code. Duct, slab, and perimeter insulation were also mentioned as areas of concern. Several specific suggestions were made:

- Develop a compliance tool or pathways for Chapter 4 MEC compliance.

- Develop tables for finding the $U$ values of typical building assemblies in ASHRAE 90.1.

- Publish the design by systems analysis (or energy cost budget) as a separate document just for those designers and building inspectors who want to buy it.

- Address ACH or mechanical ventilation or electrical efficiency measures.

See Appendix B, Question 2, for specific concerns regarding ASHRAE 90.1 and MEC 92.

\subsection{Stakeholder Groups}

The successful adoption, implementation, and enforcement of building energy codes requires that a number of groups and individuals be knowledgeable about the code and its applications. Workshop participants were asked to identify stakeholder groups in their states. Stakeholder groups identified include the following:

- $\quad$ state legislators

- builders

- $\quad$ state and local code officials (including plan reviewers)

- designers (architects and engineers)

- product suppliers

- financiers

- $\quad$ appraisers

- utilities

- $\quad$ home buyers. 
For specific organizations representing stakeholder groups identified by workshop participants, see Appendix B (Questions 3 and 4.).

Workshop participants were asked which groups or organizations are advocates and which are adversaries of the widespread adoption, implementation, and enforcement of energy-efficient building codes in their state. Although some of the above stakeholder groups were identified as both advocates and adversaries by different states, there were obvious trends. The following stakeholder groups were typically identified as advocates:

- the state energy office or related government office and code officials

- national and regional organizations supporting renewable energy and conservation, and environmental and consumer groups

- code organizations (ASHRAE, Council of American Building Officials [CABO])

- major utilities

- $\quad$ energy-efficient product manufacturers and contractors (i.e., insulation manufacturers)

- universities

- $\quad$ architects and engineers

- $\quad$ state associations of cities

Homebuilders associations and contractors associations were also listed as advocates by some respondents. Many of these different advocates have formed collaborations to encourage code implementation. For example in Massachusetts, electric utilities, the state energy office, environmental and consumer groups, and the Attorney General worked together through the Boston Edison Settlement Board and the Massachusetts Better Buildings Partnership to encourage code implementation and enforcement.

The following stakeholder groups were typically identified as adversaries to the widespread adoption, implementation, and enforcement of building energy codes by workshop participants:

- builders, home building associations, and developers who are concerned about increased costs. Lack of understanding and concerns about increased complexity and incompatibility were other reasons cited. 


\subsection{Potential Building Energy Code Implementation Partners}

- local code officials who feel they don't have the staff to do health and safety inspections, let alone energy inspections.

Encouragingly, some said they saw no active opposition to the codes in their states.

States often provide building energy code information to at least some stakeholder groups. This information is provided through reports, newsletters, and periodic presentations at stakeholder group meetings. Some states have gone further to provide comprehensive training and technical assistance on their energy code. These efforts often involve the development of partnerships with organizations that have strong connections with key stakeholder groups, or possess energy code training and technical assistance expertise.

Workshop participants identified a number of stakeholder organizations that provide information or training on building energy code adoption, implementation, and enforcement to stakeholder groups. Organizations providing information or training include

- home builder associations (such as the National Association of Home Builders [NAHB])

- $\quad$ state government departments (energy, labor, construction, natural resources, commerce, public service, etc.)

- utility companies

- codes and standards groups (such as ASHRAE, CABO, the International Conference of Building Officials [ICBO], the Southern Building Code Congress International [SBCCI], and BOCA)

- architect/engineer associations (such as the American Institute of Architects [AIA])

- associations of cities.

Means of spreading information include newsletters, meetings, workshops and conference, and videos.

For more specific information on a state-by-state basis, refer to Appendix B.

Nearly half of the survey respondents mentioned training being offered by their state. Other sources of training mentioned included utilities, state chapters of ASHRAE and other professional groups, DOE, and Energy rated homes programs. Some respondents said they were not aware of any training in their states. These responses indicate a need for more communication among individuals in a state because in some cases other respondents from the same states mentioned that training was available. 


\subsection{Technical Assistance Desired from DOE}

Training typically takes the form of workshops, one-on-one assistance, monthly and semi-annual training, annual roundtables, and newsletters. Training classes vary in comprehensiveness and target audiences. Some examples from the states are provided below:

- Utah holds 1 to 2 hour familiarization sessions for designers, architects, engineers, and building officials.

- The Ohio Builders Association of America offers comprehensive classes for building officials that are approved for continuing education credits.

- Colorado offers HERS training.

- Kentucky offers individual assistance to designers and monthly training for enforcement staff.

- Delaware is planning classes on 90.1 and MEC 93 for code officials, architects, engineers, and others.

- Iowa utilities offer MEC training workshops for builders, code officials, and others.

- Washington provides residential and commercial code assistance and training.

- Massachusetts provides code official training.

- Vermont utilities work with builders.

See Appendix B for more detail on building energy code training and technical assistance currently offered, as identified by workshop participants.

Workshop participants were asked what kind of technical assistance their state would like to receive from DOE. Participants identified an array of code involvement, training, and technical assistance activities needed to promote adoption, implementation, and enforcement of building energy codes. Those involved in building design, construction, and enforcement, such as builders, code officials, and designers, were the most commonly identified stakeholder groups that would be targeted for these building energy code training and technical assistance programs. In addition to the many requests for training, there were several specific requests for code involvement actions participants would like to see DOE take:

- Provide a means for reviewing proposed compliance paths, plans, and construction for code compliance.

- Provided comprehensive training for enforcement and compliance personnel.

- Provide on-site builder and code official assistance.

- Compile information on what works and what does not.

- Answer technical questions like "Why do I go to all the trouble to insulate and tighten my home only to install $10^{\prime \prime}$ holes for 'combustion air'? 
- $\quad$ Assess technical and economic impacts of adopting ASHRAE 90.1 and MEC 93.

- Help work out an improved licensing/royalty arrangement with CABO.

- Conduct general analysis to support state code adoption.

- Conduct technical analyses of typical homes and code scenarios showing how much savings could be expected from implementing the code; compare a home built to the code to a typical non-code home.

- Prepare economic analyses of community benefits from more stringent codes.

- $\quad$ Provide testimony if necessary.

- Provide funding for education.

- Offer individual help for code officials and departments.

Workshop participants identified a range of technical assistance and training needs. They also specified several tools and types of communication materials that could be provided or developed by DOE to meet those needs.

- Participants had several specific requests for tools including software for customizing ASHRAE 90.1 compliance, enforcement procedures, $U$ and $R$ value tables for opaque walls, an improved Federal lighting standard, and rating tools that measure compliance once a building code has officially been accepted.

- Communication materials requested included marketing materials for consumers, lenders, and realtors as well as builders to encourage energy-efficient construction; educational materials for the building community, specifically ASHRAE 90.1 and MEC 93 training materials for local building officials; codes and standards telephone hotlines; written materials and videos that could be used as training aids in code enforcement and compliance courses; and fact sheets that summarize information about the codes and standards.

- Participants stressed the need for tools that would simplify code compliance, for example, a simplified version of the ASHRAE standard, prescriptive paths for complying with the residential and commercial codes, and tables based on $R$ values instead of $U$ values. 
- One participant echoed the mission of the Building Standards and Guidelines Program in stating the need for a resource organization to respond to information requests from architects, engineers, and builders.

Participants identified the following potential topics to discuss in training, technical assistance programs, and implementation materials including

- Train-the-Trainer programs for ASHRAE and MEC, Chapter 4 compliance

- $\quad$ ASHRAE 90.1 and MEC training for engineers, architects, contractors, local building officials, and state and local enforcement personnel

- Pacific Northwest National Laboratory's MECcheck software

- National Fenestration Rating Council (NFRC) reference materials on fenestration

- compliance alternatives for code officials, builders, and architects

- $\quad$ specific MEC provision training.

\subsection{Positive Actions by the States}

\subsection{Successful State Programs}

In keeping with this year's emphasis on input from the states, workshop participants were asked what they thought was the most positive action that had taken place in their state to get building energy codes developed, adopted, implemented, and/or enforced. Their answers are summarized as follows:

- Many mentioned their states' adoption of MEC, ASHRAE or statedeveloped energy code as their state's biggest accomplishment.

- An equal number said that the cooperation of stakeholders in their state's code adoption process was the most positive action they had seen.

- Several said their state was in the process of getting legislation passed to enact or upgrade their state's energy code.

- A few mentioned DOE funding and support were very helpful.

- One said that passage of EPAct was a very positive action for his state because it forced the state to work on energy code adoption.

Workshop participants were asked to describe the most successful utilitysponsored program in their state for encouraging the design and construction of energy-efficient buildings. 
- A Michigan participant mentioned the Consumers Power Co.'s Energy Efficient Home pilot program. This program targeted residential builders, subtradesmen, realtors, and lending institutions. All homes built under the program met or exceeded the 1993 MEC. The pilot program was very successful and a full program may be implemented.

- Home Energy Ratings of Ohio (HERO), a nonprofit corporation, is working with lenders to set up energy-efficient home mortgage programs. HERO has developed a spreadsheet program that can be used to show that homes comply with the lender's requirements.

- A participant from Washington state mentioned the Northwest Energy Code's Early Adopter Program, which paved the way for the Washington State Energy Code.

- A participant from Wisconsin said that several utilities in the state conducted a rebate program for high-efficiency gas furnaces; this program was so successful that it transformed the market and rebates were no longer needed.

- Minnesota referred to its Energy Advantage Homes program which was set up by Northern States Power's gas and electric utilities and Minnesota Gas Company. The electric portion of the program has been discontinued but the Northern States Power plans to continue with the gas portion of the program, which is targeted to residential new construction.

- Participants from Idaho talked about Bonneville Power Administration's Northwest Energy Code and Super Good Cents programs.

- Utah mentioned the Utah Power and Light "Finanswer" program, a loan program for energy-efficient improvements in commercial construction sponsored by PacifiCorp. The program includes loans for energy-efficient window, insulation, and gas and electric furnaces.

- Iowa talked about IES Utilities' E+ Energy Choice Homes and Iowa-Illinois Gas \& Electric Company's "Smart Energy Shell" program along with other energy-efficiency programs that use HERS to encourage MEC compliance.

- Colorado mentioned the Energy Score Program, set up by the City of Ft. Collins Light and Power. The program allows builders to use the program's home energy rating system REM/Rate software as an alternative to prescriptive compliance with the state building code. Ft. Collins expects the Energy Score Program to generate more interest because of recent passage of a stronger state-wide energy code. 
- Rhode Island said its "Design 2000" provides rebates for air conditioning, high-efficiency motors, and energy-efficient lighting.

- Delaware mentioned Delmarva's Super E+ Program

- Massachusetts said Massachusetts Electric Company's Design 2000 program provides technical assistance in the design phase and incremental cost rebates for energy-efficiency improvements. Western Massachusetts Electric's Energy Conscious Construction program and the Energy Crafted Home program were also mentioned as successful programs.

- Maryland said Potomac Edison has good envelope, equipment and duct requirements in its Power Saver Home program. Southern Maryland Electric Cooperative has an excellent new home program that promotes high-efficiency heat pumps and gives ground source heat pump training.

- Central Vermont Public Service (CVPS) has the Assessment Fee program for residential builders in its service area. The Public Service charges builders $\$ 300$ as a building fee but gives them $\$ 750$ back if their home meets the program requirements. A home energy rating is done on the plans and the finished building. CVPS uses an electronic scorecard as a primary analysis tool to conduct inspections. For its commercial program, a typical measures list was developed to guide applicants through Vermont's decisionmaking process.

- Georgia participants mentioned Georgia Power's Super Good Cents Program, other DSM programs, and grants to homeowners to increase or bring their insulation up to code.

- Kentucky's State Department of Energy is working with customers at several utilities to develop DSM programs.

- Mississippi said the Good Cents residential program in its state has encouraged builders to improve the thermal envelopes of their homes and to install energy efficient heating, ventilation, and air conditioning (HVAC) equipment.

- North Carolina mentioned Duke Power's MAX Home, which has insulation and duct sealing provisions.

- South Carolina mentioned Carolina Power and Light's Good Cents Program which is being modified. In the past it was performance based; in the future it will be more prescriptive. Duke Power's Home Comfort Tuneup program was also mentioned. This is a retrofit program for homes. Another highly regarded program is the training school run by the North Carolina Energy Alternative 


\section{8 "Words of Advice" from Workshop Participants}

\subsection{Workshop Follow-Up}

Corporation which runs 2-week courses to train builders in heat pump installation and duct sealing.

- Tennessee said Tennessee Valley Authority's Energy Right New Homes program was a success.

Workshop participants were asked if they had any advice for others in getting building energy codes adopted, implemented, and enforced in their states. Many felt that team building and involving other stakeholders were critical. Several emphasized educating and training others. Said one participant "education is essential - keep all stakeholders informed of why things are happening. Without an exchange of ideas, information, and views, a consensus decision cannot be reached." Simplicity was also stressed. Said one participant, "keep it as simple as possible -- if the industry is educated on the codes, they will not oppose them." Several said that enacting building energy codes was an important step for future generations. As one participant said, "it's worth the pain to do something positive for the future."

The overall goal for this second series of workshops was to give states a forum for sharing lessons learned with each other as building energy codes are adopted and training programs are set up. The workshops also served as an information forum for states to learn more about MEC and ASHRAE implementation, HERS and EEMs, and assistance that DOE can provide. The workshops enabled the Building Standards and Guidelines Program to gain additional information on state needs.

This set of workshops was very successful in bringing together state officials and others involved in promoting the adoption, implementation, and enforcement of building energy codes. Attendance at the regional workshops was excellent, with staff from 38 states and two territories attending. Participants who completed workshop evaluation forms were overwhelmingly pleased with the workshop format and had relatively few suggestions for improvement. Workshop evaluation comments are presented in Appendix C.

The most popular workshop topics were MEC and ASHRAE implementation. The Home Energy Rating System talks were also very popular. Many participants were interested in the utility discussions and the state exemplary program presentations.

All of the respondents felt that the workshops provided valuable opportunities to network and all felt the presenters did a good job of presenting the information.

Workshop participants were asked if similar workshops would be useful to stakeholder groups in their state. Most believed they would be. Code officials, builders, designers, engineers, material suppliers, developers, subcontractors, appraisers, lenders, realtors, and utility representatives were all mentioned as groups that could benefit from similar workshops. 
Attendance at the regional workshops was primarily limited to state energy office staff and code officials. A number of stakeholder groups would benefit from similar workshops tailored more to their interests. Additional workshops are being contemplated for 1996 to meet the needs of these stakeholder groups. 
Appendix A

States Included in the DOE Support Office Regions 


\section{Appendix A}

\section{States Included in the DOE Support Office Regions}

\begin{tabular}{|c|c|c|}
\hline Region & DOE Contact & States in Region \\
\hline 1 & $\begin{array}{l}\text { Dave Chamberlain } \\
617 / 565-9712\end{array}$ & Connecticut, Maine, New Hampshire, Rhode Island, Vermont \\
\hline 2 & $\begin{array}{l}\text { John Golovach } \\
212 / 264-0560\end{array}$ & New Jersey, New York \\
\hline 3 & $\begin{array}{l}\text { James Frguson } \\
215 / 656-6977\end{array}$ & $\begin{array}{l}\text { Delaware, District of Columbia, Maryland, Pennsylvania, } \\
\text { Virginia, West Virginia }\end{array}$ \\
\hline 4 & $\begin{array}{l}\text { Fred Singleton } \\
404 / 347-3482\end{array}$ & $\begin{array}{l}\text { Alabama, Florida, Georgia, Kentucky, Mississippi, North } \\
\text { Carolina, Puerto Rico, South Carolina, Tennessee, Virgin } \\
\text { Islands }\end{array}$ \\
\hline 5 & $\begin{array}{l}\text { Mark Burger } \\
312 / 886-8583\end{array}$ & Illinois, Indiana, Michigan, Minnesota, Ohio, Wisconsin \\
\hline 6 & $\begin{array}{l}\text { Melanie Chambers } \\
214 / 767-7134\end{array}$ & Arkansas, Louisiana, New Mexico, Oklahoma, Texas \\
\hline 7 & $\begin{array}{l}\text { Ray Burns } \\
816 / 426-3116\end{array}$ & Iowa, Kansas, Missouri, Nebraska \\
\hline 8 & $\begin{array}{l}\text { Brian Lawson } \\
303 / 231-5750\end{array}$ & $\begin{array}{l}\text { Colorado, Montana, North Dakota, South Dakota, Utah, } \\
\text { Wyoming }\end{array}$ \\
\hline 9 & $\begin{array}{l}\text { Julia Oliver } \\
510 / 637-1952\end{array}$ & Arizona, California, Hawaii, Nevada \\
\hline 10 & $\begin{array}{l}\text { Arun Jhaveri } \\
206 / 553-2152\end{array}$ & Alaska, Idaho, Oregon, Washington \\
\hline
\end{tabular}


Appendix B

Regional Building Energy Codes and Standards

Workshop Questionnaire Responses 
Appendix B. 1995 Building Energy Codes and Standards Workshop Questionnaire Responses

\begin{tabular}{|c|c|c|c|c|c|}
\hline $\begin{array}{l}\text { ID } \\
\text { \# }\end{array}$ & $\begin{array}{l}\text { Question } \\
\text { Number }\end{array}$ & $\begin{array}{l}\text { DOE } \\
\text { Region }\end{array}$ & State & Workshop & Response \\
\hline & \multicolumn{5}{|c|}{$\begin{array}{l}\text { Question 1: In your opinion, what is the most positive action that has taken place in your state in terms of getting building energy codes developed, adopted, } \\
\text { implemented, and/or enforced, that you would like to share with others. }\end{array}$} \\
\hline 1 & 1 & 5 & MI & Chicago & $\begin{array}{l}\text { The MI Public Service Commission (PSC) is not responsible for the development, adoption, implementation } \\
\text { or enforcement of code. However, I did testify to the Senate Subcommittee in support of MEC and } \\
\text { encouraged groups/individuals to support its adoption. }\end{array}$ \\
\hline 2 & 1 & 5 & $\mathrm{OH}$ & Chicago & $\begin{array}{l}\text { The hearing/adoption process produced a dialog among designers, home builders \& code officials that } \\
\text { promoted education and interdependency. In addition, it showed that rank \& file will need training on curren } \\
\text { technologies. }\end{array}$ \\
\hline 3 & 1 & 5 & $\mathrm{OH}$ & Chicago & The statewide uniform building code with full input from all stakeholder groups. \\
\hline 4 & 1 & & NA & Chicago & Adoption of MEC 92. \\
\hline 5 & 1 & 5 & IL & Chicago & $\begin{array}{l}\text { The coalition developed by the IL Council of Code Administrators is Illinois' best leadership bet in adoption } \\
\text { of code standards in this state. }\end{array}$ \\
\hline 6 & 1 & 5 & $\mathbf{I L}$ & Chicago & IL has had little positive accomplishment. \\
\hline 7 & 1 & 10 & WA & Chicago & $\begin{array}{l}\text { Nearly every possible positive action has taken place, from adoption to implementation. All would be helpful } \\
\text { to others. }\end{array}$ \\
\hline 8 & 1 & 5 & WI & Chicago & It is an ongoing process. \\
\hline 9 & 1 & 5 & MN & Chicago & $\begin{array}{l}\text { MN received strong legislative support (since 1974) but no funding). The utility conservation improvement } \\
\text { programs will be a significant influence at time of next code upgrade: provide good education, work out } \\
\text { practical problems between stakeholders \& provide case studies. }\end{array}$ \\
\hline 10 & 1 & 10 & ID & Denver & $\begin{array}{l}\text { To date, the most positive action has been the proposal for residential energy code upgrade, funded by DOE, } \\
\text { coupled with cooperation of the local offices of HUD and VA. }\end{array}$ \\
\hline 11 & 1 & 8 & UT & Denver & Change by the administrative role rather than legislative action. \\
\hline 12 & 1 & 7 & IOU & Denver & $\begin{array}{l}\text { Adoption of ASHRAE } 90.1 \text { (1992 MEC previously adopted) into Iowa state building code allowed Iowa to } \\
\text { obtain progressive building energy code education grant. }\end{array}$ \\
\hline 13 & 1 & 8 & $\mathrm{CO}$ & Denver & The support of the CO Office of Energy Conservation on technical issues, training and software development. \\
\hline
\end{tabular}




\begin{tabular}{|c|c|c|c|c|c|}
\hline ID & $\begin{array}{l}\text { Question } \\
\text { Number }\end{array}$ & $\begin{array}{l}\text { DOE } \\
\text { Region }\end{array}$ & State & Workshop & Response \\
\hline 14 & 1 & 1 & RI & Boston & Receiving grant from US DOE to fund implementation and enforcement. \\
\hline 15 & 1 & 3 & $\mathrm{DE}$ & Boston & $\begin{array}{l}\text { The active participation of the affected parties. The willingness of DE Code Officials, Homebuilders's Assoc., } \\
\text { Architect's Assoc. \& others to listen/consider the merits of a stronger code has led to adoption of CABO } \\
\text { MEC } 1993 \text { as the DE state standard. }\end{array}$ \\
\hline 16 & 1 & 1 & MA & Boston & $\begin{array}{l}\text { 1) Successful initiative in } 1987 \text { to establish a state building energy code. 2) A new initiative to upgrade the } \\
\text { building energy code began this spring. }\end{array}$ \\
\hline 17 & 1 & 3 & MD & Boston & $\begin{array}{l}\text { Legislation that established latest BOCA edition as state energy code. Law has loopholes, but provides decent } \\
\text { foundation for upgrade to CABO MEC \& ASHRAE 90.1. Also Codes administration publishes all county \& } \\
\text { municipality code requirements. }\end{array}$ \\
\hline 18 & 1 & 2 & NY & Boston & $\begin{array}{l}\text { NY State Energy Office was abolished effective } 3 / 31 / 95 \text {. Codes Bureau (this office) will be required to } \\
\text { assume function of the Energy Office pending legislative approval. Therefore, we don't have answers to any } \\
\text { of these questions. }\end{array}$ \\
\hline 19 & 1 & 1 & VT & Boston & $\begin{array}{l}\text { Dialogue between key parties on residential codes and development of modified ASHRAE standards for } \\
\text { state-funded new construction. }\end{array}$ \\
\hline 20 & 1 & 1 & VT & Boston & $\begin{array}{l}\text { In Fall ' } 94 \text { \& Spring ' } 95 \text {, we sponsored several meetings with utility representatives, Energy Rated Homes of } \\
\text { VT and the Homebuilders' Assoc. to discuss DSM program design and code related issues. }\end{array}$ \\
\hline 21 & 1 & 4 & AL & Atlanta & $\begin{array}{l}\text { 1) Formation of Steering Comm. to work on Residential Energy Code of AL (RECA) 2) Current state } \\
\text { legislative efforts to create a Res. Energy Code Board and to adopt the CABO MEC. }\end{array}$ \\
\hline 22 & 1 & 4 & GA & Atlanta & $\begin{array}{l}\text { GA has revised ' } 92-95 \text { MEC \& ASHRAE 90.1. Taskforce to review } 95 \text { MEC \& expand ASHRAE } 90.1 \text { in } \\
\text { simple terms is currently "sally up" (?) }\end{array}$ \\
\hline 23 & 1 & 4 & GA & Atlanta & Education \\
\hline 24 & 1 & 4 & GA & Atlanta & $\begin{array}{l}\text { Recent adoption of revised code increased building community awareness of code. We've seen some } \\
\text { improvements, most visible in greater use of insulated glazing. Also, utility programs now concerned about } \\
\text { not being in compliance with code. }\end{array}$ \\
\hline 25 & 1 & 4 & GA & Atlanta & Adoption \& enforcement of DSM programs. \\
\hline 26 & 1 & 4 & KY & Atlanta & $\begin{array}{l}\text { Residential building energy code MEC } 92 \text { recommended by the KY Board of Housing, Bldgs. \& Construction } \\
\text { (the Board) was adopted by the KY Dept. of Housing, Bldgs. \& Construction (KDHBC). }\end{array}$ \\
\hline
\end{tabular}




\begin{tabular}{|c|c|c|c|c|c|}
\hline $\begin{array}{l}\text { ID } \\
\text { \# }\end{array}$ & $\begin{array}{l}\text { Question } \\
\text { Number }\end{array}$ & $\begin{array}{l}\text { DOE } \\
\text { Region }\end{array}$ & State & Workshop & Response \\
\hline 27 & 1 & 4 & MS & Atlanta & $\begin{array}{l}\text { The Dept. of Economics \& Comm. Development Host Q\&A workshops throughout the state to get input } \\
\text { before trying to get a bill passed. }\end{array}$ \\
\hline 28 & 1 & 4 & $\mathrm{NC}$ & Atlanta & Cooperation of Energy Division, Dept. of Insurance and Home Builders Assoc. \\
\hline 29 & 1 & 4 & SC & Atlanta & \\
\hline 30 & 1. & 4 & $\mathrm{TN}$ & Atlanta & MEC 92 has been adopted. \\
\hline 31 & 1 & 4 & $\mathrm{TN}$ & Atlanta & $\begin{array}{l}\text { EPAct. Tennessee's statues on Energy Code haven't changed since } 1978 \text { and probably would not have } \\
\text { without EPAct. }\end{array}$ \\
\hline 32 & 1 & 4 & USVI & Atlanta & $\begin{array}{l}\text { VIEO developed the "V.I. Code for Energy Conservation in New Building Construction" in } 1990 \text {. It } \\
\text { addresses water, energy conservation in building of all sized and types (new/mechanically air conditioned), } \\
\text { and encourages use of design techniques, energy systems, \& energy efficient materials in VI climate. It has } \\
\text { yet to be implemented, however. }\end{array}$ \\
\hline 33 & 1 & 4 & WV & Atlanta & Legislation presented to '95 legislature to upgrade code to BOCA '93. \\
\hline
\end{tabular}


1995 BUILDING ENERGY CODES AND STANDARDS WORKSHOP QUESTIONNAIRE RESPONSES

\begin{tabular}{|c|c|c|c|c|c|}
\hline $\begin{array}{l}\text { ID } \\
\#\end{array}$ & $\begin{array}{l}\text { Question } \\
\text { Number }\end{array}$ & $\begin{array}{l}\text { DOE } \\
\text { Region }\end{array}$ & State & Workshop & Response \\
\hline & \multicolumn{5}{|c|}{ Question 2: What specific concerns do you have in your state with regards to the building code requirements of EPAct? } \\
\hline 1 & 2 & 5 & MI & Chicago & $\begin{array}{l}\text { The individual inspectors \& bldg. officials who will be implementing/enforcing the code in } \\
\text { many areas of the state lack necessary tools and expertise to fulfill these functions. }\end{array}$ \\
\hline 2 & 2 & 5 & $\mathrm{OH}$ & Chicago & $\begin{array}{l}\text { The necessity of developing a compliance tool or set of pathways for chapter. } 4 \text { MEC } \\
\text { compliance. }\end{array}$ \\
\hline 3 & 2 & 5 & $\mathrm{OH}$ & Chicago & $\begin{array}{l}\text { Education: all stakeholders need to be informed of the new 90.1/MEC requirements. } \\
\text { Designers aren't yet educated; this may create short-term enforcement problems. }\end{array}$ \\
\hline 4 & 2 & & NA & Chicago & Compliance. \\
\hline 5 & 2 & 5 & IL & Chicago & $\begin{array}{l}\text { Too complex for many builders. Acceptance will require development of tools/materials } \\
\text { which simplify them greatly, along with training. }\end{array}$ \\
\hline 6 & 2 & 5 & IL & Chicago & Getting anything accepted as Code. \\
\hline 7 & 2 & 5 & WA & Chicago & $\begin{array}{l}\text { In general, code language should be very specific and uncomplicated. Vague language is } \\
\text { more harmful than helpful, for it encourages inconsistent interpretation, eventually eroding } \\
\text { credibility of code. Complicated requirements require more support (hotlines, training \& } \\
\text { written, technical assistance). }\end{array}$ \\
\hline 8 & 2 & 5 & WI & Chicago & How to structure code for CABO MEC 95. Skip MEC 92. \\
\hline 9 & 2 & 5 & MN & Chicago & $\begin{array}{l}90.1 \text { envelope criteria need to be more simplified, including tables for finding } U \text {-values of } \\
\text { typical bldg. assemblies (eg. steel stud table). Would be desirable if the design by systems } \\
\text { analysis (or energy cost budget) method would be published as a separate document so that } \\
\text { just those designers and bldg. inspection offices using it would have to buy a copy. }\end{array}$ \\
\hline 10 & 2 & 10 & ID & Denver & $\begin{array}{l}\text { Builders are concerned with the requirement to insulate floors while Fed/State agencies are } \\
\text { concerned with implementing MEC responsibly. A firm, clear and consistent interpretation } \\
\text { is necessary. }\end{array}$ \\
\hline 11 & 2 & 8 & UT & Denver & $\begin{array}{l}\text { Delays in receipt of training materials; ACP table coverage inadequate; cost-effectiveness } \\
\text { data. }\end{array}$ \\
\hline
\end{tabular}




\begin{tabular}{|c|c|c|c|c|c|}
\hline $\begin{array}{l}\text { ID } \\
\#\end{array}$ & $\begin{array}{l}\text { Question } \\
\text { Number }\end{array}$ & $\begin{array}{l}\text { DOE } \\
\text { Region }\end{array}$ & State & Workshop & Response \\
\hline 12 & 2 & 7 & IA & Denver & $\begin{array}{l}\text { 1. There is a need for bldg. energy codes training and education. 2. IA State Bldg. Code } \\
\text { Commissioners lacks funds and staff to adequately work on energy codes. 3. Need to } \\
\text { encourage small cities, towns to comply with and enforce energy codes. }\end{array}$ \\
\hline 13 & 2 & 8 & $\mathrm{CO}$ & Denver & $\begin{array}{l}\text { Indoor Air quality, conflicts with other code requirements (i.e., combustion air for fuel- } \\
\text { burning appliances). }\end{array}$ \\
\hline 14 & 2 & 1 & RI & Boston & Making the codes understandable and easy to use so compliance will be simplified. \\
\hline 15 & 2 & 3 & $\mathrm{DE}$ & Boston & $\begin{array}{l}\text { 1. Increased cost to the homebuilders. 2. training 3. enforcement mechanisms and 4. added } \\
\text { inspections. }\end{array}$ \\
\hline 16 & 2 & 1 & MA & Boston & $\begin{array}{l}\text { 1. ASHRAE } 90.1 \text { (89) needs to be updated. We want to use the national MEC to update } \\
\text { MA code, but the } 89 \text { version is old. Look forward to ASHRAE } 90.1 \text { (RES.) } 2 \text {. The royalty } \\
\text { licensing requirements of CABO are a barrier to code upgrades in MA. It wold help to have } \\
\text { additional options to compensate CABO beyond a royalty fee for every copy distributed. }\end{array}$ \\
\hline 17 & 2 & 3 & MD & Boston & No response. \\
\hline 18 & 2 & 2 & NY & Boston & See response to Q.\#1: Codes Bureau not able to answer at this time. \\
\hline 19 & 2 & 1 & VT & Boston & $\begin{array}{l}\text { Inspection/enforcement once a code is passed. Also, education of builders/A\&E and } \\
\text { developers. Vermont's capability to do this is virtually non-existent at this time. }\end{array}$ \\
\hline 20 & 2 & 1 & VT & Boston & $\begin{array}{l}\text { MEC } 92 \text { does not seem to address ACH or mechanical ventilation requirements. Nor does it } \\
\text { address electrical efficiency measures. We will want to link any code VT adopts with } \\
\text { effective utility DSM programs. }\end{array}$ \\
\hline 21 & 2 & 4 & $\mathrm{AL}$ & Atlanta & $\begin{array}{l}\text { For implementation, codes need to be easy to understand. All codes (some bldg. code, } \\
\text { CABO, ASHRAE) need to be comparable and compatible. }\end{array}$ \\
\hline 22 & 2 & 4 & GA & Atlanta & $\begin{array}{l}\text { Need to continue to train building officials, builders \& designers in "How To" meet codes. } \\
\text { Real problem is enforcement and how to enforce. }\end{array}$ \\
\hline 23 & 2 & 4 & GA & Atlanta & Getting the general public aware that there is a energy code. \\
\hline 24 & 2 & 4 & GA & Atlanta & $\begin{array}{l}\text { 1. enforcement 2. enforcement } 3 \text {. enforcement } 4 \text {. several issues related to cooling, } \\
\text { termites/slab insulation, and lack of focus on air sealing building envelope or duct systems, } \\
\text { and of course, enforcement. }\end{array}$ \\
\hline
\end{tabular}




\begin{tabular}{|c|c|c|c|c|c|}
\hline ID & $\begin{array}{l}\text { Question } \\
\text { Number }\end{array}$ & $\begin{array}{l}\text { DOE } \\
\text { Region }\end{array}$ & State & Workshop & Response \\
\hline 25 & 2 & 4 & GA & Atlanta & That they are not being enforced. \\
\hline 26 & 2 & 4 & KY & Atlanta & $\begin{array}{l}\text { MEC } 92 \text { - None. ASHRAE } 90.1 \text {, because the scope of change is so significant, staff time to } \\
\text { understand will be large, domino-ing as staff communicate to all stakeholders. Will also } \\
\text { increase plan review/approval time within KDHBC from 10-15 to } 25-30 \text { working days. } \\
\text { KDHBC staff levels are capped. }\end{array}$ \\
\hline 27 & 2 & 4 & MS & Atlanta & $\begin{array}{l}\text { Any restrictions on end-use equipment based on anything other than actual weather } \\
\text { conditions and utility rates. }\end{array}$ \\
\hline 28 & 2 & 4 & $\mathrm{NC}$ & Atlanta & Enforcement, particularly air sealing and duct sealing aspects. \\
\hline 29 & 2 & 4 & SC & Atlanta & \\
\hline 30 & 2 & 4 & TN & Atlanta & $\begin{array}{l}\text { 1. Perimeter insulation: termite problems, depth required may be greater than depth of } \\
\text { foundation; slabs both conditioned/unconditioned. } 2 \text {. Chap. } 6 \text { is too busy with tables, } \\
\text { references, etc. 3. Cooling load not builder-friendly (leads to) local interpretations. }\end{array}$ \\
\hline 31 & 2 & 4 & TN & Atlanta & None \\
\hline 32 & 2 & 4 & USVI & Atlanta & The code's relevance to the Caribbean climate. \\
\hline 33 & 2 & 3 & WV & Atlanta & $\begin{array}{l}\text { BOCA } 93 \text { includes both ASHRAE } 90.1 \text { \& MEC } 92 \text {. However, it gives an alternative that is } \\
\text { less stringent. Would like to see a BOCA code that accepts only } 90.1 \text { \& MEC } 92 \text {. }\end{array}$ \\
\hline
\end{tabular}


1995 BUILDING ENERGY CODES AND STANDARDS WORKSHOP QUESTIONNAIRE RESPONSES

\begin{tabular}{|c|c|c|c|c|c|}
\hline $\begin{array}{l}\text { ID } \\
\#\end{array}$ & $\begin{array}{l}\text { Question } \\
\text { Number }\end{array}$ & $\begin{array}{l}\text { DOE } \\
\text { Region }\end{array}$ & State & Workshop & Response \\
\hline & \multicolumn{5}{|c|}{$\begin{array}{l}\text { Question 3: What groups/organizations have been advocates for the adoption/upgrading and/or the widespread implementation and } \\
\text { enforcement of building energy codes in your state? Please describe how each group helped facilitate the implementation and/or enforcement of } \\
\text { building energy codes. }\end{array}$} \\
\hline 1 & 3 & 5 & MI & Chicago & $\begin{array}{l}\text { MEC has only recently been adopted and local Homebuilders Assoc. resisted its passage. } \\
\text { One local non-profit, Urban Options, and individual advocates (i.e., comm. college profs. and } \\
\text { material suppliers) have supported implementation. Support resulted from public meeting } \\
\text { and testifying at senate hearings. }\end{array}$ \\
\hline 2 & 3 & 5 & $\mathrm{OH}$ & Chicago & $\begin{array}{l}\text { OEE: Information dissemination through liaison with OBBS and other groups. OEE } \\
\text { delivered testimony at Board hearing. Ohio Consultive Council of Nat ' } 1 \text { Inst. of Bldg.Science } \\
\text { (OCC/NIBS) provided a debate forum for stakeholders in bldg. code concerns and they } \\
\text { were mostly supportive. DOE/PNL staff provided expert testimony; OH Bd. of Bldg. } \\
\text { Standards staff, Home Energy Ratings of OH Foundation, utilities in general. }\end{array}$ \\
\hline 3 & 3 & 5 & $\mathrm{OH}$ & Chicago & Code enforcers, designers, suppliers and government. \\
\hline 4 & 3 & & NA & Chicago & No response. \\
\hline 5 & 3 & 5 & IL & Chicago & Code officials, homebuilders (as part of a comprehensive building code). \\
\hline 6 & 3 & 5 & $\mathrm{IL}$ & Chicago & $?$ \\
\hline 7 & 3 & 10 & WA & Chicago & $\begin{array}{l}\text { Assoc. of WA Cities provided annual conference \& newsletters; provided cities with code } \\
\text { adoption procedures \& formats. WA Assoc. of Bldg. Officials provided certification tests. } \\
\text { Utilities provided } \$ \text { and input at all levels. }\end{array}$ \\
\hline 8 & 3 & 5 & WI & Chicago & Advisory group for commercial energy code. \\
\hline 9 & 3 & 5 & $\mathrm{MN}$ & Chicago & $\begin{array}{l}\text { State legislature (in spirit, if not } \$ \text { ), Builders Association of MN (within last } 5 \text { years) helped } \\
\text { by organizing meetings to discuss proposed code amendments. }\end{array}$ \\
\hline 10 & 3 & 10 & ID & Denver & $\begin{array}{l}\text { ID Dept. of Water Resources, Energy Division; Assoc. of ID Cities; BPA were primary } \\
\text { proponents. Interested parties in lesser energy codes are Idaho's investor-owned gas \& } \\
\text { electric utilities; PUC; ID Bldg. Contractors Assoc. Also participating is the ID fenestration } \\
\text { industry and building code officials. }\end{array}$ \\
\hline
\end{tabular}




\begin{tabular}{|c|c|c|c|c|c|}
\hline $\begin{array}{l}\text { ID } \\
\text { \# }\end{array}$ & $\begin{array}{l}\text { Question } \\
\text { Number }\end{array}$ & $\begin{array}{l}\text { DOE } \\
\text { Region }\end{array}$ & State & Workshop & Response \\
\hline 11 & 3 & 8 & UT & Denver & $\begin{array}{l}\text { Office of Energy Services; Division of Prof. Licensing; DES requested UT Engineer Exp.Sta. } \\
\text { (UEES) to act as "shepherd" in adoption process for EC and MEC. DOPL licenses all } \\
\text { inspectors but must first ascertain they are trained. }\end{array}$ \\
\hline 12 & 3 & 7 & IA & Denver & $\begin{array}{l}\text { IA State Building Code Commissioner in IA Dept. of Public Safety very supportive of } \\
\text { ASHRAE } 90.1 \text { adoption because of EPAct requirements. IA utilities support training and } \\
\text { including home energy ratings/code compliance in residential new construction e.e. } \\
\text { programs. IA Energy Center provided a grant to the IA Assoc. of Municipal Utilities for } \\
\text { MEC education, survey \& production of builder's video regarding MEC and formation of } \\
\text { task forces along with two workshops. }\end{array}$ \\
\hline 13 & 3 & 8 & $\mathrm{CO}$ & Denver & $\begin{array}{l}\text { Office of Energy Conservation, local Board of Appeals and local Bldg. officials supported the } \\
\text { code by providing technical support and speaking at local city council meeting during public } \\
\text { hearings. }\end{array}$ \\
\hline 14 & 3 & 1 & RI & Boston & $\begin{array}{l}\text { Utility companies provided rebates and education. Builders' Energy Crafted Homes, builder } \\
\text { education. State Energy Office provided Federal Assistance programs. Financial institutions - } \\
\text { higher debt/income ratios. }\end{array}$ \\
\hline 15 & 3 & 3 & DE & Boston & $\begin{array}{l}\text { State of Delaware Energy Office, Delmarva Power. Energy office proposed legislation to } \\
\text { adopt CABO MEC 93, which passed 6/95. Demarva Power proposed joint effort on } \\
\text { providing training/technical assistance for code officials, builders, architects, etc. with the } \\
\text { state. }\end{array}$ \\
\hline 16 & 3 & 1 & MA & Boston & $\begin{array}{l}\text { Electric utilities, state energy office, environmental/consumer groups (i.e., Conservation Law } \\
\text { Foundation, MASS-PIRG) and the Attorney General. They are currently working together } \\
\text { through Boston Edison DSM Settlement Bd. and just-forming MA Better Buildings } \\
\text { Partnership to upgrade/improve bldg. energy code implementation/enforcement. In May, } \\
\text { Settlement Bd. requested formal hearing at MA Board of Bldg. Regulations \& Standards to } \\
\text { consider several amendments to the code to increase EE in res/comm. new construction, } \\
\text { which was actively supported by the E.O., A.G., CLF, and several electric/gas utilities. Delay } \\
\text { possible if DOE rejects MA Better Buildings grant request, by DOER. }\end{array}$ \\
\hline 17 & 3 & 3 & MD & Boston & $\begin{array}{l}\text { 1. Utilities want energy demand windfall from strict code compliance so they don' } t \text { have to } \\
\text { pay rebates for new home programs, but don' } t \text { want to alienate customers. They were } \\
\text { passive supporters of legislation. } 2 \text {. Conservation/Environmental groups pushed for passage. } \\
\text { 3. Some large statewide builders wanted consistent code. }\end{array}$ \\
\hline
\end{tabular}




\begin{tabular}{|c|c|c|c|c|c|}
\hline $\begin{array}{l}\text { ID } \\
\#\end{array}$ & $\begin{array}{l}\text { Question } \\
\text { Number }\end{array}$ & $\begin{array}{l}\text { DOE } \\
\text { Region }\end{array}$ & State & Workshop & Response \\
\hline 18 & 3 & 2 & NY & Boston & see response to Q.\#1 \\
\hline 19 & 3 & 1 & VT & Boston & $\begin{array}{l}\text { Residential: Homebuilders Assoc. of No. VT worked to pass CABO/MEC statewide. } \\
\text { Commercial: ASHRAE Vermont Chapter, VT utilities to a lesser degree. VT utilities have } \\
\text { supported inspection of ACT } 250 \text { projects and have programs using E-Rated Homes in } \\
\text { compliance with residential ACT } 250 \text {. }\end{array}$ \\
\hline 20 & 3 & 1 & VT & Boston & $\begin{array}{l}\text { Homebuilders Assoc. of N.VT pushed for adoption of CABO/MEC. My dept. will support } \\
\text { this only if it doesn' } t \text { undercut VT's ACT } 250 \text { standard which is a lifecycle cost standard, } \\
\text { applying to } 50 \% \text { of residential new construction in Vermont. }\end{array}$ \\
\hline 21 & 3 & 4 & $\mathrm{AL}$ & Atlanta & $\begin{array}{l}\text { AL Dept. of Economic \& Community Affairs, Science, Tech. \& Energy Division; Res. } \\
\text { Energy Conservation Service; AL Gas Co., AL Power Co., Mobile Gas Service; AL Electric } \\
\text { Coops; AL Gas Bd., AL Council of AIA, AL Homebuilders Assoc, Bd. of General } \\
\text { Contractors, Home Builders License Bd., HUD; AL Assoc. of Realtors; Legislative Fiscal } \\
\text { Office; Dept.of Bldg. Science, Auburn Univ., AL League of Municipalities; Farmers Home } \\
\text { Admin., independent contractors\&builders. }\end{array}$ \\
\hline 22 & 3 & 4 & GA & Atlanta & $\begin{array}{l}\text { Building Official Assoc. of GA (BOAG) held classes. Dept. of Comm. Affairs chaired } \\
\text { Energy Comm. meetings, some seminars. Utilities assisted in training classes. Univ. of GA } \\
\text { did training classes. Homebuilders Assoc. conducted classes on trades-off worksheets.. }\end{array}$ \\
\hline 23 & 3 & 4 & GA & Atlanta & No response. \\
\hline 24 & 3 & 4 & GA & Atlanta & $\begin{array}{l}\text { GA Div. of Energy Resources, GA Dept. of Comm. Affairs assisted in development \& } \\
\text { adoption of code, also providing limited training. Little has been done to encourage } \\
\text { enforcement. Southface Energy Institute conducted study of code compliance for GA office } \\
\text { of Consumer Affairs. Southface provides technical assistance on ad hoc basis to utilities, } \\
\text { building professionals, etc. }\end{array}$ \\
\hline 25 & 3 & 4 & GA & Atlanta & Southface Energy Institute facilitated in may ways including educating the consumer. \\
\hline 26 & 3 & 4 & KY & Atlanta & $\begin{array}{l}\text { KDOE advocated adoption, implementation \& enforcement and taught an annual Graduate } \\
\text { Builders Institute course under sponsorship of Home Builders Assoc. of KY. KDOE also } \\
\text { prepared USDOE grant application for KDHBC as part of 4-state submittal with NC as lead } \\
\text { state. }\end{array}$ \\
\hline 27 & 3 & 4 & MS & Atlanta & Engineering community. \\
\hline
\end{tabular}




\begin{tabular}{||l||l|l|l|l|l||}
\hline $\begin{array}{l}\text { ID } \\
\text { \# }\end{array}$ & $\begin{array}{l}\text { Question } \\
\text { Number }\end{array}$ & $\begin{array}{l}\text { DOE } \\
\text { Region }\end{array}$ & State & Workshop & Response \\
\hline \hline 28 & 3 & 4 & NC & Atlanta & $\begin{array}{l}\text { NC Energy Division orchestrated meetings and provided technical input. Building Codes } \\
\text { Council passes provision recommended by the Energy Committee, which had builders, utility } \\
\text { personnel \& state officials as members. }\end{array}$ \\
\hline 29 & 3 & 4 & SC & Atlanta & $\begin{array}{l}\text { SC Energy Office, private consulting firms, SC Building Codes Council all promoted } \\
\text { building/energy codes for years. Enforcement officials promoted aggressively as they became } \\
\text { more knowledgeable. Inspector associations have been non-committal. }\end{array}$ \\
\hline 30 & 3 & 4 & TN & Atlanta & $\begin{array}{l}\text { TN State Energy Office, TVA, private interest groups, and recently some help from the } \\
\text { Homebuilders Assoc. office. }\end{array}$ \\
\hline 31 & 3 & 4 & TN & Atlanta & $\begin{array}{l}\text { Southface Institute, State of TN, TVA, and local utilities jointly sponsored open workshops. } \\
\text { Code enforcement hasn't been uniform. Middle Tenn. probably doing the best enforcement. } \\
\text { Generally, local utilities have been supportive throughout the state. }\end{array}$ \\
\hline 32 & 3 & 4 & USVI & Atlanta & $\begin{array}{l}\text { VIEO remains the sole advocate for implementing/enforcing building codes, so far } \\
\text { unsuccessfully. }\end{array}$ \\
\hline 33 & 3 & 4 & WV & Atlanta & WV architects (i.e., Frances Gruffy) and recently the WV Homebuilders Association. \\
\hline \hline
\end{tabular}


1995 BUILDING ENERGY CODES AND STANDARDS WORKSHOP QUESTIONNAIRE RESPONSES

\begin{tabular}{|c|c|c|c|c|c|}
\hline $\begin{array}{l}\text { ID } \\
\text { \# }\end{array}$ & $\begin{array}{l}\text { Question } \\
\text { Number }\end{array}$ & $\begin{array}{l}\text { DOE } \\
\text { Region }\end{array}$ & State & Workshop & Response \\
\hline & \multicolumn{5}{|c|}{$\begin{array}{l}\text { Question 4: What groups/organizations have been opposed to the adoption/upgrading of a building energy code? a. What has been the main } \\
\text { point(s) of opposition by these groups? }\end{array}$} \\
\hline 1 & 4 & 5 & MI & Chicago & Local Home Builders Association (HBA) opposes the additional costs. \\
\hline 2 & 4 & 5 & $\mathbf{O H}$ & Chicago & The Ohio Homebuilders Assoc. has been opposed. \\
\hline 3 & 4 & 5 & $\mathbf{O H}$ & Chicago & $\begin{array}{l}\text { 1. Residential single-family builders opposed the added complexity of compliance (OH used } \\
\text { to have one prescriptive set of requirements with no calculations). } 2 \text {. Some code officials and } \\
\text { designers opposed to any energy provisions as a part of the building code. They don't } \\
\text { consider this a life-safety issue. }\end{array}$ \\
\hline 4 & 4 & & NA & Chicago & Builders \\
\hline 5 & 4 & 5 & IL & Chicago & Illinois Municipal League \\
\hline 6 & 4 & 5 & IL & Chicago & same as above \\
\hline 7 & 4 & 10 & WA & Chicago & Building Industry Assoc. of WA, Republican legislators. \\
\hline 8 & 4 & 5 & WI & Chicago & Builders opposed MEC because of their lack of understanding. \\
\hline 9 & 4 & 5 & $\mathrm{MN}$ & Chicago & Generally, building officials opposed any changes. \\
\hline 10 & 4 & 10 & ID & Denver & $\begin{array}{l}\text { Builders oppose stringent codes, especially Central ID builders. (N. and SE Idaho builders } \\
\text { generally supported the Power Council's Model Conservation standards.) Investor-owned } \\
\text { utilities and PUC support the Central Idaho builders for political reasons, their main motive } \\
\text { is to save capital cost on the front end. }\end{array}$ \\
\hline 11 & 4 & 8 & UT & Denver & Homebuilders Association - lost. \\
\hline 12 & 4 & 7 & IA & Denver & $\begin{array}{l}\text { Iowa builders are don 't want to include basement insulation in homes because it adds to the } \\
\text { cost of new homes. Also, many builders believe homeowners should decide if they want } \\
\text { basement insulation instead of the builder providing it as part of MEC cost-effectiveness. }\end{array}$ \\
\hline 13 & 4 & 8 & $\mathrm{CO}$ & Denver & $\begin{array}{l}\text { Homebuilders Assoc. and large tract home developers oppose because of cost and } \\
\text { affordability issues. }\end{array}$ \\
\hline
\end{tabular}




\begin{tabular}{|c|c|c|c|c|c|}
\hline $\begin{array}{l}\text { ID } \\
\#\end{array}$ & $\begin{array}{l}\text { Question } \\
\text { Number }\end{array}$ & $\begin{array}{l}\text { DOE } \\
\text { Region }\end{array}$ & State & Workshop & Response \\
\hline 14 & 4 & 1. & RI & Boston & There was no opposition to the revised code, adopting MEC 93, at the public hearing. \\
\hline 15 & 4 & 3 & $\mathrm{DE}$ & Boston & $\begin{array}{l}\text { Some contractors have been opposed. Main opposition points are: increased cost to customer } \\
\text { and the extra inspection requirements. }\end{array}$ \\
\hline 16 & 4 & 1 & MA & Boston & $\begin{array}{l}\text { The opposition to upgrades has not yet voiced objection. We are already meeting with } \\
\text { parties affected by code changes to get their input/feedback on proposed amendments. }\end{array}$ \\
\hline 17 & 4 & 3 & MD & Boston & $\begin{array}{l}\text { 1. Small Builders say it will unnecessarily increase costs. } 2 \text {. Local code officials indicate thy } \\
\text { don't have staff to do health/safety inspections, let alone energy. } 3 \text {. Local officials don't } \\
\text { want to relinquish local control; described as an unfunded mandate. }\end{array}$ \\
\hline 18 & 4 & 2 & NY & Boston & see response to $Q \# 1$ \\
\hline 19 & 4 & 1 & VT & Boston & $\begin{array}{l}\text { State of VT DPS cautiously supports codes where they can make a difference. Baseline study } \\
\text { should clarify whether VT builds residential to CABO MEC level or not. DPS is concerned } \\
\text { that ACT } 250 \text { not be replaced until equal or better results can be obtained. Some } \\
\text { environmental groups have similar concerns. }\end{array}$ \\
\hline 20 & 4 & 1 & VT & Boston & $\begin{array}{l}\text { Interestingly, the organizations and groups, including the VT Public Service Dept. who are } \\
\text { strong environmental advocates, have opposed code proposals that would have the effect of } \\
\text { undercutting ACT } 250 \text {. }\end{array}$ \\
\hline 21 & 4 & 4 & $\mathrm{AL}$ & Atlanta & $\begin{array}{l}\text { No major opposition is known, except to make codes compatible. There is concern over } \\
\text { implementation of codes and inspection networks. }\end{array}$ \\
\hline 22 & 4 & 4 & GA & Atlanta & $\begin{array}{l}\text { Opposition stems from a lack of understanding of the building codes; when designers and } \\
\text { contractors understand "how to" issues, such opposition is diminished. }\end{array}$ \\
\hline 23 & 4 & 4 & GA & Atlanta & General contractors are most opposed to the upgrading of building codes. \\
\hline 24 & 4 & 4 & GA & Atlanta & $\begin{array}{l}\text { There is opposition from: 1) homebuilders associations, who claim stricter codes will increase } \\
\text { costs; 2) local code agencies who claim stricter codes increase their workload; 3) vendors of } \\
\text { inefficient windows who fear reduced sales; and 5) the Dept. of Comm. Affairs, for reasons } \\
\text { unknown. }\end{array}$ \\
\hline 25 & 4 & 4 & GA & Atlanta & No comment \\
\hline
\end{tabular}




\begin{tabular}{|c|c|c|c|c|c|}
\hline ID & $\begin{array}{l}\text { Question } \\
\text { Number }\end{array}$ & $\begin{array}{l}\text { DOE } \\
\text { Region }\end{array}$ & State & Workshop & Response \\
\hline 26 & 4 & 4 & KY & Atlanta & $\begin{array}{l}\text { No active or organized opposition to ASHRAE } 90.1 \text {; the reluctance of adopting } 90.1 \text { stems } \\
\text { from a lack of understanding of the code's impact, benefits and associated costs. This lack } \\
\text { of knowledge is due primarily to resource constraints. No opposition to CABO MEC } 92 \text {, }\end{array}$ \\
\hline 27 & 4 & 4 & MS & Atlanta & Home builders due to perceived increased costs and architects (no reason specified). \\
\hline 28 & 4 & 4 & $\mathrm{NC}$ & Atlanta & $\begin{array}{l}\text { Home builders, who are not formally opposed but grudgingly accepts stricter codes. } \\
\text { However, they are opposed to enforcement procedures, i.e. posting forms. }\end{array}$ \\
\hline 29 & 4 & 4 & SC & Atlanta & $\begin{array}{l}\text { Opposition comes from the Associations of Municipalities and Counties because it removes } \\
\text { local authority over the codes; both groups use an "unfunded mandate" argument to support } \\
\text { thier position. The home builders oppose it, claiming increased costs. }\end{array}$ \\
\hline 30 & 4 & 4 & TN & Atlanta & $\begin{array}{l}\text { The Tennessee Home Builders Association opposes stricter codes, claiming it is too } \\
\text { confusing and will increase their members' costs. }\end{array}$ \\
\hline 31 & 4 & 4 & TN & Atlanta & $\begin{array}{l}\text { Builder groups, as opposed to individual builders, and it is not clear how truly these } \\
\text { organizations represent their members. I think anytime something is mandated, there will be } \\
\text { opposition. }\end{array}$ \\
\hline 32 & 4 & 4 & USVI & Atlanta & Not applicable, as now building codes have been implemented. \\
\hline 33 & 4 & 3 & WV & Atlanta & Historically, home builders have been opposed, while code officials remain neutral. \\
\hline
\end{tabular}


1995 BUILDING ENERGY CODES AND STANDARDS WORKSHOP QUESTIONNAIRE RESPONSES

\begin{tabular}{|c|c|c|c|c|c|}
\hline \# & $\begin{array}{l}\text { Question } \\
\text { Number }\end{array}$ & $\begin{array}{l}\text { DOE } \\
\text { Region }\end{array}$ & State & Workshop & Response \\
\hline & \multicolumn{5}{|c|}{$\begin{array}{l}\text { Question 5: What organizations provide information on building energy code development, adoption, implementation and enforcement of } \\
\text { stakeholder groups (i.e., designers, code officials, builders) in your state? Describe how information is provided, to whom and how frequently. }\end{array}$} \\
\hline 1 & 5 & 5 & MI & Chicago & $\begin{array}{l}\text { The Department of Labor Construction, Code Division, and the Department of Commerce } \\
\text { which provides newsletters, phone calls and information from non-profits. }\end{array}$ \\
\hline 2 & 5 & 5 & $\mathrm{OH}$ & Chicago & $\begin{array}{l}\text { OCC/NIBS, which hold monthly fora for code issues, and NIBS makes recommendations to } \\
\text { the Ohio Board of Building Standards (OBBS); members are informed through a newsletter } \\
\text { and meeting minutes. The local chapter of AIA has provided information as well. }\end{array}$ \\
\hline 3 & 5 & 5 & $\mathbf{O H}$ & Chicago & BOCA, OBBS, professional groups and contractor groups. \\
\hline 4 & 5 & & NA & Chicago & No response. \\
\hline 5 & 5 & 5 & $\Pi$ & Chicago & $\begin{array}{l}\text { The Department of Energy \& Natural Resources provides funding support for code training } \\
\text { in eastern IL as well as general information on energy codes. They also do on-site training } \\
\text { by request. }\end{array}$ \\
\hline 6 & 5 & 5 & IL & Chicago & No response. \\
\hline 7 & 5 & 10 & WA & Chicago & $\begin{array}{l}\text { WSEO, which provides press releases, newsletters and a hotline; utilities who give } \\
\text { presentations; Assoc. of WA Cities which put together conferences, newsletters and } \\
\text { workshops; and WA Building Officials, who hold workshops and prepare newsletters. }\end{array}$ \\
\hline 8 & 5 & 5 & WI & Chicago & $\begin{array}{l}\text { The Department of Industry, Labor and Human Relations prepares newsletters and holds } \\
\text { annual training programs. }\end{array}$ \\
\hline 9 & 5 & 5 & MN & Chicago & $\begin{array}{l}\text { The State Department of Public Service and the Department of Administration, Building } \\
\text { Code Division prepare newsletters, write articles and hold workshops. }\end{array}$ \\
\hline 10 & 5 & 10 & ID & Denver & $\begin{array}{l}\text { The Energy Division does builder training and technical assistance; Local Government } \\
\text { Energy Committee publishes a monthly newspaper ("Monthly Currents") which targets } \\
\text { builders and homebuyers. }\end{array}$ \\
\hline 11 & 5 & 8 & UT & Denver & $\begin{array}{l}\text { UEES provides personal contact to building inspectors, architects and engineers as } \\
\text { requested. This will be improved as more funding comes in. }\end{array}$ \\
\hline
\end{tabular}




\begin{tabular}{|c|c|c|c|c|c|}
\hline $\begin{array}{l}\text { ID } \\
\#\end{array}$ & $\begin{array}{l}\text { Question } \\
\text { Number }\end{array}$ & $\begin{array}{l}\text { DOE } \\
\text { Region }\end{array}$ & State & Workshop & Response \\
\hline 12 & 5 & 7 & IA & Denver & $\begin{array}{l}\text { Battelle provided technical assistance through a presentation at the } 1994 \text { IA Bldg. Codes \& } \\
\text { Standards Advisory Committee meeting. This Committee was established by the DNR to } \\
\text { educate stakeholders on the adoption of } 90.1 \text {. }\end{array}$ \\
\hline 13 & 5 & 8 & $\mathrm{CO}$ & Denver & $\begin{array}{l}\text { The Office of Energy Conservation provides reports, cities (such as Fort Collins) prepare } \\
\text { reports, manufacturers prepare videos and provide technical assistance, and the Public } \\
\text { Service Company provides brochures on its Ideal Energy Home Program. }\end{array}$ \\
\hline 14 & 5 & 3 & RI & Boston & $\begin{array}{l}\text { The State Building Commission placed a newspaper ad announcing the public hearing, and } \\
\text { provides information on the codes }{ }^{\circ} \text { effects on current practices. }\end{array}$ \\
\hline 15 & 5 & 1 & $\mathrm{DE}$ & Boston & $\begin{array}{l}\text { Delmarva Power \& Light, State ASHRAE chapter, the State Energy Office and the BOCA } \\
\text { chapter all provide information by special arrangements, such as seminars or workshops. }\end{array}$ \\
\hline 16 & 5 & 3 & MA & Boston & The Board of Building Regulation \& Standards provides information. \\
\hline 17 & 5 & 1 & MD & Boston & $\begin{array}{l}\text { The Dept. of Housing \& Community Development, Code Administration has a local code } \\
\text { requirements database. The MD HBA has developed training materials and the Alliance to } \\
\text { Save Energy developed a "report card" and other publications. }\end{array}$ \\
\hline 18 & 5 & 2 & NY & Boston & No Comment \\
\hline 19 & 5 & 1 & VT & Boston & $\begin{array}{l}\text { VT Department of Public Service (DPS), builders, Department of Labor \& Industry, utilities } \\
\text { and the Home Builder Association of Northern VT (HBANVT) have all provided } \\
\text { information. }\end{array}$ \\
\hline 20 & 5 & 1 & VT & Boston & DPS, HBANVT and Energy Rated Homes of VT have all provided information. \\
\hline 21 & 5 & 4 & AL & Atlanta & $\begin{array}{l}\text { ADECA provides letters and copies of the code to interested parties, the HBA provides } \\
\text { newsletters and utilities provide newsletters. }\end{array}$ \\
\hline 22 & 5 & 4 & GA & Atlanta & HBA through classes and their magazine, ad industry through literature, classes and videos. \\
\hline 23 & 5 & 4 & GA & Atlanta & $\begin{array}{l}\text { Greater Atlanta Home Builders and the HBA of GA sponsor classes on the State Energy } \\
\text { Code; GA Power provided materials for these classes. }\end{array}$ \\
\hline 24 & 5 & 4 & GA & Atlanta & $\begin{array}{l}\text { The Dept. of Comm. Affairs and the State Code Official Association provide infrequent } \\
\text { communication via newsletters and presentations. Southface Energy Institute includes } \\
\text { articles in its newsletter, hotline requests and infrequent inclusion of code info in training } \\
\text { actions. }\end{array}$ \\
\hline
\end{tabular}




\begin{tabular}{|c|c|c|c|c|c|}
\hline $\begin{array}{l}\text { ID } \\
\#\end{array}$ & $\begin{array}{l}\text { Question } \\
\text { Number }\end{array}$ & $\begin{array}{l}\text { DOE } \\
\text { Region }\end{array}$ & State & Workshop & Response \\
\hline 25 & 5 & 4 & GA & Atlanta & No Response \\
\hline 26 & 5 & 4 & KY & Atlanta & $\begin{array}{l}\text { The KY DOE and the KY HBA taught a course, "Energy Efficient Construction." The KY } \\
\text { Dept. of Housing, Building and Construction provides semi-annual training for local } \\
\text { enforcement officials and one-on-one assistance to design professionals on an as-needed } \\
\text { basis. This organization also distributes a newsletter approximately } 2-3 \text { times a year. }\end{array}$ \\
\hline 27 & 5 & 4 & MS & Atlanta & $\begin{array}{l}\text { Utilities attempt to provide information through one-on-one meetings with the Department } \\
\text { or Energy. }\end{array}$ \\
\hline 28 & 5 & 4 & $\mathrm{NC}$ & Atlanta & $\begin{array}{l}\text { The Energy Division takes phone calls, holds seminars and sponsored Southface to perform } \\
6 \text { one day workshops for builders and code officials. The Department of Insurance provides } \\
\text { telephone information, occasional memoranda to code officials. }\end{array}$ \\
\hline 29 & 5 & 4 & SC & Atlanta & $\begin{array}{l}\text { The State Energy Office acts as a clearinghouse for code issues, holds seminars and provides } \\
\text { input for legislation. The SC Building Code Council promote the code on an on-going basis; } \\
\text { private consulting firms promote it during inspections and litigation and utilities coordinate } \\
\text { the code with their efficiency programs. }\end{array}$ \\
\hline 30 & 5 & 4 & TN & Atlanta & $\begin{array}{l}\text { Code officials and TVA provide training. Additionally, TVA's efficiency programs recognize } \\
\text { MEC. }\end{array}$ \\
\hline 31 & 5 & 4 & TN & Atlanta & $\begin{array}{l}\text { The State Energy Office contacted local jurisdictions to tell them about impending } \\
\text { legislation, a trainer budget was established to hold workshops throughout the state, and } \\
\text { TVA's local utilities were contacted to co-sponsor workshops, and a stakeholder database } \\
\text { was established. }\end{array}$ \\
\hline 32 & 5 & 4 & USVI & Atlanta & The VIEO provides energy efficient building guidelines in the form of flyers and newsletters. \\
\hline 33 & 5 & 3 & WV & Atlanta & $\begin{array}{l}\text { The State Fire Marshall Office contacted stakeholders, including designers, homebuilders, } \\
\text { code officials and engineers; correspondence is the means of information dissemination. }\end{array}$ \\
\hline
\end{tabular}


1995 BUILDING ENERGY CODES AND STANDARDS WORKSHOP QUESTIONNAIRE RESPONSES

\begin{tabular}{|c|c|c|c|c|c|}
\hline $\begin{array}{l}\text { ID } \\
\#\end{array}$ & $\begin{array}{l}\text { Question } \\
\text { Number }\end{array}$ & $\begin{array}{l}\text { DOE } \\
\text { Region }\end{array}$ & State & Workshop & Response \\
\hline & \multicolumn{5}{|c|}{$\begin{array}{l}\text { Question 6: What training and/or technical assistance is currently provided in your state to those responsible for implementing designers, } \\
\text { architects, engineers) and enforcing building energy codes, and who provides this support? Of these which ones might be useful to other states? }\end{array}$} \\
\hline 1 & 6 & 5 & MI & Chicago & The Dept. of Labor is responsible for technical assistance. \\
\hline 2 & 6 & 5 & $\mathrm{OH}$ & Chicago & $\begin{array}{l}\text { NAIMA MEC training is sponsored through OBOA for building officials and is approved for } \\
\text { CEUs through the OBBS. Dayton P\&L once sponsored a seminar on } 90.1 \text {. }\end{array}$ \\
\hline 3 & 6 & 5 & $\mathbf{O H}$ & Chicago & Implementing training is provided by professional groups at their members' requests. \\
\hline 4 & 6 & & NA & Chicago & Did not know. \\
\hline 5 & 6 & 5 & IL & Chicago & DENR provides training support. \\
\hline 6 & 6 & 5 & IL & Chicago & None. \\
\hline 7 & 6 & 10 & WA & Chicago & $\begin{array}{l}\text { WSEO provides residential assistance, the utilities code group provides commercial code } \\
\text { assistance, and full code training is available to all. }\end{array}$ \\
\hline 8 & 6 & 5 & WI & Chicago & DIHLR (no explanation given). \\
\hline 9 & 6 & 5 & $\mathrm{MN}$ & Chicago & $\begin{array}{l}\text { The Dept. of Public Service publishes the Homebuilders Energy Update and there is a } \\
\text { building inspection technology class. }\end{array}$ \\
\hline 10 & 6 & 10 & ID & Denver & $\begin{array}{l}\text { The Energy Division provides training to Northwest Energy Code enforcers at two } \\
\text { roundtables per year plus addresses enforcement issues at annual builder training meetings. }\end{array}$ \\
\hline 11 & 6 & 8 & UT & Denver & $\begin{array}{l}\text { UEES holds "familiarization" sessions for } 1 \text { to } 2 \text { hours are held for designers, architects, } \\
\text { engineers and building officials. }\end{array}$ \\
\hline 1 & 6 & 7 & IA & Denver & $\begin{array}{l}\text { The IA utilities provided the MEC training workshops for builders, code officials and others. } \\
\text { The IA BCC staff does not have the time or money to provide training. }\end{array}$ \\
\hline 2 & 6 & 8 & $\mathrm{CO}$ & Denver & $\begin{array}{l}\text { The Office of Energy Conservation provides technical support \& representation to local } \\
\text { officials as well as HERS training. Energy Rated Homes of CO has provided some limited } \\
\text { training. }\end{array}$ \\
\hline
\end{tabular}




\begin{tabular}{|c|c|c|c|c|c|}
\hline $\begin{array}{l}\text { ID } \\
\#\end{array}$ & $\begin{array}{l}\text { Question } \\
\text { Number }\end{array}$ & $\begin{array}{l}\text { DOE } \\
\text { Region }\end{array}$ & State & Workshop & Response \\
\hline 14 & 6 & 1 & RI & Boston & $\begin{array}{l}\text { Seminars for code enforcement officials on MEC } 93 \text { provided by Dave Conover (PNL) and } \\
\text { Steve Turchen (DOE). }\end{array}$ \\
\hline 15 & 6 & 3 & DE & Boston & $\begin{array}{l}\text { Currently none. Workshops are being planned for Fall } 95 \text { to educate on } 90.1 \text { and MEC } 93 \\
\text { for code officials, architects, engineers and others. Delmarva Power and State ASHRAE } \\
\text { chapter will join with the state in this effort. }\end{array}$ \\
\hline 16 & 6 & 1 & MA & Boston & $\begin{array}{l}\text { Training is provided by the Board of Building Regs and Standards for code officials. } \\
\text { Additional training is provided by trade associations and universities. Utilities provide } \\
\text { limited training through their residential DSM programs. }\end{array}$ \\
\hline 17 & 6 & 3 & MD & Boston & $\begin{array}{l}\text { NAHB offers MEC training to its members, and Codes Administration provides limited } \\
\text { training. }\end{array}$ \\
\hline 18 & 6 & 2 & NY & Boston & N/A \\
\hline 19 & 6 & 1 & VT & Boston & ERH VT does limited inspection of residential buildings and VT utilities work with builders. \\
\hline 20 & 6 & 1 & VT & Boston & $\begin{array}{l}\text { Utilities, ERH VT and DPS provide specific dealer training seminars on energy efficiency in } \\
\text { residential and new construction. }\end{array}$ \\
\hline 21 & 6 & 4 & $\mathrm{AL}$ & Atlanta & Not applicable at this time. \\
\hline 22 & 6 & 4 & GA & Atlanta & $\begin{array}{l}\text { DCA has worked with the Energy Department to hold classes for building officials and } \\
\text { contractors. This educating might be useful for other states, as long as classes are in simple } \\
\text { "bubba" terms }\end{array}$ \\
\hline 23 & 6 & 4 & GA & Atlanta & $\begin{array}{l}\text { Classes are held throughout GA. The trainer comes from the University of GA (The Carl } \\
\text { Vincent Institute of Government, Center for Continuing Education). }\end{array}$ \\
\hline 24 & 6 & 4 & GA & Atlanta & $\begin{array}{l}\text { None that is state supported. Southface has developed a workshop that could easily be } \\
\text { adapted to other states. }\end{array}$ \\
\hline 25 & 6 & 4 & GA & Atlanta & Some seminars through Southface funded by DOE. \\
\hline 26 & 6 & 4 & KY & Atlanta & $\begin{array}{l}\text { The KY DOE and the KY HBA taught a course, "Energy Efficient Construction." The KY } \\
\text { Dept. of Housing, Building and Construction provides semi-annual training for local } \\
\text { enforcement officials and one-on-one assistance to design professionals on an as-needed } \\
\text { basis. KDHBC conducts monthly training for central office enforcement staff. }\end{array}$ \\
\hline
\end{tabular}




\begin{tabular}{|c|c|c|c|c|c|}
\hline $\begin{array}{l}\text { ID } \\
\#\end{array}$ & $\begin{array}{l}\text { Question } \\
\text { Number }\end{array}$ & $\begin{array}{l}\text { DOE } \\
\text { Region }\end{array}$ & State & Workshop & Response \\
\hline 27 & 6 & 4 & MS & Atlanta & None is given. \\
\hline 28 & 6 & 4 & NC & Atlanta & $\begin{array}{l}\text { The Energy Division has sponsored } 6 \text { workshops and does frequent yet brief presentations on } \\
\text { MEC; no training on } 90.1 \text { as of yet. }\end{array}$ \\
\hline 29 & 6 & 4 & $\mathrm{SC}$ & Atlanta & No response \\
\hline 30 & 6 & 4 & TN & Atlanta & The State Energy Office and TVA have done some limited training. \\
\hline 31 & 6 & 4 & TN & Atlanta & $\begin{array}{l}\text { The State is primarily responsible for training. A few localities have conducted code } \\
\text { workshops without the assistance of vendors. Additional, the local ASHRAE chapter is } \\
\text { interested in code training. }\end{array}$ \\
\hline 32 & 6 & 4 & USVI & Atlanta & N/A \\
\hline 33 & 6 & 3 & wV & Atlanta & $\begin{array}{l}\text { None. BOCA offers a series of workshops and includes sites in WV. The State Fire } \\
\text { Marshall received a grant to provide training on building energy efficiency; these will begin } \\
\text { in the fall of } 1995 \text {. }\end{array}$ \\
\hline
\end{tabular}


1995 BUILDING ENERGY CODES AND STANDARDS WORKSHOP QUESTIONNAIRE RESPONSES

\begin{tabular}{|c|c|c|c|c|c|}
\hline $\begin{array}{l}\text { ID } \\
\#\end{array}$ & $\begin{array}{l}\text { Question } \\
\text { Number }\end{array}$ & $\begin{array}{l}\text { DOE } \\
\text { Region }\end{array}$ & State & Workshop & Response \\
\hline & \multicolumn{5}{|c|}{ Question 7: What specific types of technical assistance would you like DOE to provide to your state? } \\
\hline 1 & 7 & 5 & MI & Chicago & Training and marketing. \\
\hline 2 & 7 & 5 & OH & Chicago & Train the Trainer programs for ASHRAE \& MEC. Training on Chapter 4 compliance \\
\hline 3 & 7 & 5 & $\mathrm{OH}$ & Chicago & $\begin{array}{l}\text { Plan review and intent of the code, construction review and proposed compliance path } \\
\text { review/evaluation. }\end{array}$ \\
\hline 4 & 7 & & NA & Chicago & Train the trainer. \\
\hline 5 & 7 & 5 & IL & Chicago & $\begin{array}{l}\text { More comprehensive training for both enforcement \& compliance personnel throughout the } \\
\text { state. Information pertaining to current construction practices in IL along with information } \\
\text { on incremental costs of compliance. }\end{array}$ \\
\hline 6 & 7 & 5 & IL & Chicago & None. \\
\hline 7 & 7 & 10 & WA & Chicago & $\begin{array}{l}\text { Hotlines, on-site builder/code official assistance (WESO provides both for residential, only } \\
\text { hotline for non-residential). }\end{array}$ \\
\hline 8 & 7 & 5 & WI & Chicago & Software 90.1 compliance customizing for code enforcement. \\
\hline 9 & 7 & 5 & $\mathrm{MN}$ & Chicago & $\begin{array}{l}\text { Training sessions for building officials, simplified standard and a Federal lighting standard } \\
\text { that works. }\end{array}$ \\
\hline 10 & 7 & 10 & ID & Denver & PNL's software and prescriptive paths. \\
\hline 11 & 7 & 8 & UT & Denver & $\begin{array}{l}\text { Training aides (text, video); reference materials (NFRC on fenestration, } U \text { or } R \text { value tables } \\
\text { for opaque walls; persuasion materials. }\end{array}$ \\
\hline 12 & 7 & 7 & IA & Denver & $\begin{array}{l}\text { There is a need to educate engineers, architects, contractors and others on 90.1. The IA } \\
\text { DNR will issue an RFP to provide energy code training to many stakeholders. Can PNL } \\
\text { provide a mailing list of people who may wish out respond to this RFP? }\end{array}$ \\
\hline 13 & 7 & 8 & $\mathrm{CO}$ & Denver & $\begin{array}{l}\text { Information on the "state-of-the-art," what works and what does not, answers to questions } \\
\text { such as, "why do I go to all the trouble to insulate and tighten my homes only to install 10" } \\
\text { holes for combustion air?" }\end{array}$ \\
\hline
\end{tabular}




\begin{tabular}{|c|c|c|c|c|c|}
\hline ID & $\begin{array}{l}\text { Question } \\
\text { Number }\end{array}$ & $\begin{array}{l}\text { DOE } \\
\text { Region }\end{array}$ & State & Workshop & Response \\
\hline 14 & 7 & 1 & RI & Boston & Local Building Official training. Training on 90.1 and MEC 93 , including materials. \\
\hline 15 & 7 & 3 & $\mathrm{DE}$ & Boston & $\begin{array}{l}\text { Assessment of technical and economic impacts of adopting } 90.1 \text { and MEC 93; this is needed } \\
\text { in ASAP to support a formal code upgrade next spring. Also, assistance is needed in } \\
\text { working out improved licensing/royalty arrangements with CABO. }\end{array}$ \\
\hline 16 & 7 & 1 & MA & Boston & More training for code officials, builders and architects on compliance alternatives. \\
\hline 17 & 7 & 3 & MD & Boston & N/A \\
\hline 18 & 7 & 2 & NY & Boston & General analysis to support code adoption \\
\hline 19 & 7 & 1 & VT & Boston & Support to assist VT in adopting code, i.e. general guidance. \\
\hline 20 & 7 & 1 & VT & Boston & $\begin{array}{l}\text { Technical analysis of various typical homes and code scenarios. It would be useful to show } \\
\text { specifically how much savings could be expected from implementing the code. Comparing a } \\
\text { home built to code to a typical non-code home or a VT Act } 250 \text { home would be useful. }\end{array}$ \\
\hline 21 & 7 & 4 & $\mathrm{AL}$ & Atlanta & Implementation. \\
\hline 22 & 7 & 4 & GA & Atlanta & Simple ways to meet the code (i.e., tables based on $\mathbf{R}$ Values, as opposed to $\mathbf{u}$ values.) \\
\hline 23 & 7 & 4 & GA & Atlanta & More educating of Building Officials. \\
\hline 24 & 7 & 4 & GA & Atlanta & $\begin{array}{l}\text { Simple compliance tools, training, economic analyses of community benefits from stricter } \\
\text { codes and a hotline. }\end{array}$ \\
\hline 25 & 7 & 4 & GA & Atlanta & Enforcement procedures. \\
\hline 26 & 7 & 4 & KY & Atlanta & $\begin{array}{l}\text { Comprehensive training on } 90.1 \text {, including training for state and local enforcement personnel, } \\
\text { testimony if necessary, simplified code enforcement materials, educational materials for the } \\
\text { building community and some sort of resource organization to respond to requests from } \\
\text { architects, engineers and builders. }\end{array}$ \\
\hline 27 & 7 & 4 & MS & Atlanta & No response. \\
\hline 28 & 7 & 4 & NC & Atlanta & $\begin{array}{l}\text { Overall } 90.1 \text { training and specific MEC provision training as well as fact sheets. Telephone } \\
\text { hotline and technical assistance. }\end{array}$ \\
\hline 29 & 7 & 4 & SC & Atlanta & Education (and funding for the education). \\
\hline
\end{tabular}




\begin{tabular}{|l|l|l|l|l|l|}
\hline $\begin{array}{l}\text { ID } \\
\text { \# }\end{array}$ & $\begin{array}{l}\text { Question } \\
\text { Number }\end{array}$ & $\begin{array}{l}\text { DOE } \\
\text { Region }\end{array}$ & State & Workshop & Response \\
\hline \hline 30 & 7 & 4 & TN & Atlanta & Local code officials/departments need individual help. \\
\hline 31 & 7 & 4 & TN & Atlanta & Resources are limited, and the types of assistance varies over time. \\
\hline 32 & 7 & 4 & USVI & Atlanta & $\begin{array}{l}\text { Once a building energy code has been officially accepted and implemented, rating tools that } \\
\text { measure adherence to the energy code warrants technical assistance. Technical assistance } \\
\text { would also be needed to assure accurate code requirements suitable to the USVI climate. }\end{array}$ \\
\hline 33 & 7 & 3 & WV & Atlanta & Training on codes. \\
\hline
\end{tabular}


1995 BUILDING ENERGY CODES AND STANDARDS WORKSHOP QUESTIONNAIRE RESPONSES

\begin{tabular}{|c|c|c|c|c|c|}
\hline $\begin{array}{l}\text { ID } \\
\#\end{array}$ & $\begin{array}{l}\text { Question } \\
\text { Number }\end{array}$ & $\begin{array}{l}\text { DOE } \\
\text { Region }\end{array}$ & State & Workshop & Response \\
\hline & \multicolumn{5}{|c|}{$\begin{array}{l}\text { Question 8: Discuss one example of a utility program in your state that you believe has been very successful in encouraging the design and } \\
\text { construction of energy-efficient buildings. }\end{array}$} \\
\hline 1 & 8 & 5 & MI & Chicago & $\begin{array}{l}\text { Consumers Power Co in Jackson, MI had an Energy Efficient Home pilot program which } \\
\text { encouraged those involved in the home building/sales to construct or market homes that met } \\
\text { or exceeded the } 1993 \text { MEC. The program was very successful, so a full program will be } \\
\text { implemented. }\end{array}$ \\
\hline 2 & 8 & 5 & $\mathrm{OH}$ & Chicago & N/A \\
\hline 3 & 8 & 5 & $\mathrm{OH}$ & Chicago & $\begin{array}{l}\text { Home Energy Ratings of Ohio (HERO) encourages energy conservation to be considered in } \\
\text { new and existing homes. The program is attempting to address a segment of the market not } \\
\text { included in the building codes. }\end{array}$ \\
\hline 4 & 8 & & NA & Chicago & Rebates and incentives for the installation of insulation, furnaces, low-e windows, etc... \\
\hline 5 & 8 & 5 & IL & Chicago & None. \\
\hline 6 & 8 & 5 & IL & Chicago & No response. \\
\hline 7 & 8 & 10 & WA & Chicago & NWEC's Early Adopter Program paved the way for the WSEC. \\
\hline 8 & 8 & 5 & WI & Chicago & $\begin{array}{l}\text { Rebates for high efficiency furnaces transformed the market and these rebates no longer } \\
\text { exist. }\end{array}$ \\
\hline 9 & 8 & 5 & MN & Chicago & Energy Advantage Homes (information can be obtained from MN DPS). \\
\hline 10 & 8 & 10 & ID & Denver & BPA's Northwest Energy Code program and Super Good Cents program. \\
\hline 11 & 8 & 8 & UT & Denver & UP\&L's "Finanswer" program (for more info, contact UEES). \\
\hline 12 & 8 & 7 & IA & Denver & $\begin{array}{l}\text { IES Utilities ' E+ Energy Choice Homes and Iowa-Illinois Gas \& Electric Co's "Smart } \\
\text { Energy Shell" program are two residential new const. EE programs that use HERS to } \\
\text { encourage MEC ' } 92 \text { compliance. }\end{array}$ \\
\hline 13 & 8 & 8 & $\mathrm{CO}$ & Denver & Ft. Collins is the best example with their Energy Source program. \\
\hline 14 & 8 & 1 & RI & Boston & "Design 2000" provides rebates for air conditioning, HEMs and EE lighting. \\
\hline
\end{tabular}




\begin{tabular}{|c|c|c|c|c|c|}
\hline $\begin{array}{l}\text { ID } \\
\#\end{array}$ & $\begin{array}{l}\text { Question } \\
\text { Number }\end{array}$ & $\begin{array}{l}\text { DOE } \\
\text { Region }\end{array}$ & State & Workshop & Response \\
\hline 15 & 8 & 3 & $\mathrm{DE}$ & Boston & Delmarva's Super E+ Program. \\
\hline 16 & 8 & 1 & MA & Boston & $\begin{array}{l}\text { MA Elec. Co's Design } 200 \text { program provides technical assistance in the design phase and } \\
\text { incremental cost rebates for EE improvements. Also Western Massachusetts Electric's } \\
\text { Energy Conscious Construction program and the Energy Crafted Home program. }\end{array}$ \\
\hline 17 & 8 & 3 & MD & Boston & $\begin{array}{l}\text { Potomac Edison has good envelope, equipment and duct requirements in its power saver } \\
\text { home program. Southern MD Electric Coop (SMECO) has an excellent new home program } \\
\text { which promotes high efficiency heat pumps and gives ground source heat pump training. }\end{array}$ \\
\hline 18 & 8 & 2 & NY & Boston & N/A \\
\hline 19 & 8 & 1 & VT & Boston & $\begin{array}{l}\text { The Washington Electric Cooperative's residential program incorporates ERH VT ratings as } \\
\text { tools to educate decision makers. Also CVPS's commercial program developed a typical } \\
\text { measures list to guide ACT } 250 \text { applicants through the decision making process. }\end{array}$ \\
\hline 20 & 8 & 1 & VT & Boston & $\begin{array}{l}\text { The Washington Electric Cooperative's residential program is getting high participation and } \\
\text { a high penetration of energy efficiency measures. We feel this is a model program and are } \\
\text { trying to get it implemented in several utility service territories. }\end{array}$ \\
\hline 21 & 8 & 4 & $\mathrm{AL}$ & Atlanta & N/A \\
\hline 22 & 8 & 4 & GA & Atlanta & GA Power's Super Good Cents Program. \\
\hline 23 & 8 & 4 & GA & Atlanta & Grants to homeowners to increase or bring their insulation up to code. \\
\hline 24 & 8 & 4 & GA & Atlanta & $\begin{array}{l}\text { GA Power's Super Good Cents program which does blower door tests and duct leakage } \\
\text { tests. }\end{array}$ \\
\hline 25 & 8 & 4 & GA & Atlanta & GA Power's DSM programs. \\
\hline 26 & 8 & 4 & KY & Atlanta & $\mathrm{KDOE}$ is working with customers at several utilities to develop DSM programs. \\
\hline 27 & 8 & 4 & MS & Atlanta & $\begin{array}{l}\text { The Good Cents residential program; it has encouraged builders to improve the thermal } \\
\text { envelopes of their homes and install EE HVAC equipment. }\end{array}$ \\
\hline 28 & 8 & 4 & NC & Atlanta & Duke Power's MAX Home, which has insulation and duct sealing provisions. \\
\hline 29 & 8 & 4 & SC & Atlanta & The Good Cents program and the Common Cents program. \\
\hline 30 & 8 & 4 & TN & Atlanta & TVA's Energy Right New Homes program. \\
\hline
\end{tabular}




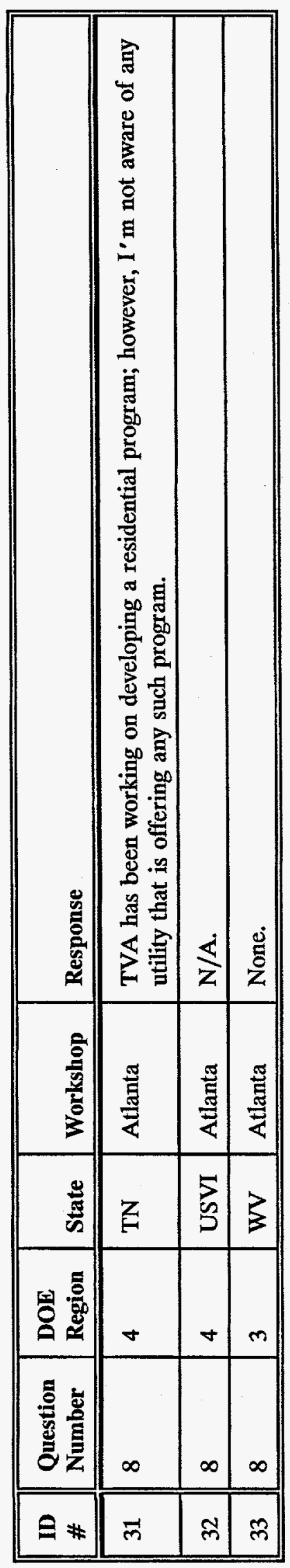

กุ 
1995 BUILDING ENERGY CODES AND STANDARDS WORKSHOP QUESTIONNAIRE RESPONSES

\begin{tabular}{|c|c|c|c|c|c|}
\hline $\begin{array}{l}\text { ID } \\
\text { \# }\end{array}$ & $\begin{array}{l}\text { Question } \\
\text { Number }\end{array}$ & $\begin{array}{l}\text { DOE } \\
\text { Region }\end{array}$ & State & Workshop & Response \\
\hline & \multicolumn{5}{|c|}{$\begin{array}{l}\text { Question 9: If you could provide other states with one "word of advice" in terms of building energy code adoption/upgrade, implementation, or } \\
\text { enforcement, what would it be? }\end{array}$} \\
\hline 1 & 9 & 5 & MI & Chicago & $\begin{array}{l}\text { More training for home builders to show how to achieve compliance at minimal increased } \\
\text { cost. In addition, help builders to market their homes as better built, more comfortable and } \\
\text { reduced energy cost. }\end{array}$ \\
\hline 2 & 9 & 5 & $\mathrm{OH}$ & Chicago & N/A \\
\hline 3 & 9 & 5 & OH & Chicago & $\begin{array}{l}\text { Education is essential -- keep all stakeholders informed of why things are happening. } \\
\text { Without an exchange of ideas, information and views, a consensus decision cannot be } \\
\text { reached. }\end{array}$ \\
\hline 4 & 9 & 5 & NA & Chicago & Get support from all parties being affected. \\
\hline 5 & 9 & 5 & IL & Chicago & N/A \\
\hline 6 & 9 & 5 & IL & Chicago & Educate political entities. \\
\hline 7 & 9 & 10 & WA & Chicago & 1) Hotline; 2) simple, clear requirements; and 3) provide training. \\
\hline 8 & 9 & 5 & WI & Chicago & $\begin{array}{l}\text { Keep your eye on where you are trying to go so that the pressures don't detract from the } \\
\text { ultimate movement forward. }\end{array}$ \\
\hline 9 & 9 & 5 & $\mathrm{MN}$ & Chicago & $\begin{array}{l}\text { For residential, builders need to know it is in their interest to build energy efficient homes. } \\
\text { For commercial, efficiency will always be code-driven. Lighting is much more important } \\
\text { than the envelope in terms of energy savings potential. }\end{array}$ \\
\hline 10 & 9 & 10 & ID & Denver & $\begin{array}{l}\text { Be fair, but always keep in mind the long term benefit of the people who buy and live in the } \\
\text { homes built to these standards. While energy costs may be in a downswing, these homes will } \\
\text { last longer than these ephemeral market conditions. }\end{array}$ \\
\hline 11 & 9 & 8 & UT & Denver & $\begin{array}{l}\text { Delay "effective" date until training can be concluded for a majority of architects and } \\
\text { builders. }\end{array}$ \\
\hline 12 & 9 & 7 & IA & Denver & $\begin{array}{l}\text { Collaborative teamwork. Involve stakeholders in a State Building Code Advisory Committee. } \\
\text { Ask for Battelle's technical assistance in educating this Committee. }\end{array}$ \\
\hline
\end{tabular}




\begin{tabular}{|c|c|c|c|c|c|}
\hline $\begin{array}{l}\text { ID } \\
\#\end{array}$ & $\begin{array}{l}\text { Question } \\
\text { Number }\end{array}$ & $\begin{array}{l}\text { DOE } \\
\text { Region }\end{array}$ & State & Workshop & Response \\
\hline 13 & 9 & 8 & $\mathrm{CO}$ & Denver & Just do it. It's worth the pain to do something positive for the future. \\
\hline 14 & 9 & 1 & RI & Boston & Simplicity. \\
\hline 15 & 9 & 3 & $\mathrm{DE}$ & Boston & $\begin{array}{l}\text { Seek the interest and cooperation of the affected parties. Make them a part of the process } \\
\text { and keep them informed. }\end{array}$ \\
\hline 16 & 9 & 1 & MA & Boston & Be patient, remain focused seek feedback and input from everyone. \\
\hline 17 & 9 & 3 & MD & Boston & Training and consensus building early on usually makes it easier for passage of legislation. \\
\hline 18 & 9 & 2 & NY & Boston & N/A \\
\hline 19 & 9 & 1 & VT & Boston & $\begin{array}{l}\text { Develop partnerships and the necessary infrastructure to educate players from code through } \\
\text { enforcement. }\end{array}$ \\
\hline 20 & 9 & 1 & VT & Boston & $\begin{array}{l}\text { Build coalitions of various interests to create the consensus for a value of adopting an energy } \\
\text { efficient building code. }\end{array}$ \\
\hline 21 & 9 & 4 & AL & Atlanta & $\begin{array}{l}\text { Involve all the key players from the beginning and form a dialogue for consensus -- no } \\
\text { surprises. }\end{array}$ \\
\hline 22 & 9 & 4 & GA & Atlanta & Train at Bubba's level and have SIMPLE tables and checklists. \\
\hline 23 & 9 & 4 & GA & Atlanta & Know your codes, \\
\hline 24 & 9 & 4 & GA & Atlanta & $\begin{array}{l}\text { The MEC does not equal insulation, it's not what the spec but what you inspect and } 502.4 \\
\text { and } 503.10 \text { rule! }\end{array}$ \\
\hline 25 & 9 & 4 & GA & Atlanta & Good Luck! \\
\hline 26 & 9 & 4 & KY & Atlanta & $? ?$ \\
\hline 27 & 9 & 4 & MS & Atlanta & No response. \\
\hline 28 & 9 & 4 & NC & Atlanta & Simplify, gain consensus with code inspectors \& builders. \\
\hline 29 & 9 & 4 & $\mathrm{SC}$ & Atlanta & $\begin{array}{l}\text { Keep it as simple as possible -- if the industry is educated on the codes, they will not oppose } \\
\text { them. }\end{array}$ \\
\hline 30 & 9 & 4 & TN & Atlanta & Get builders involved up-front. \\
\hline
\end{tabular}




\begin{tabular}{|c|c|c|c|}
\hline 惹 & 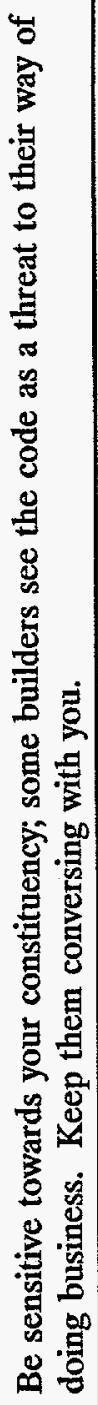 & 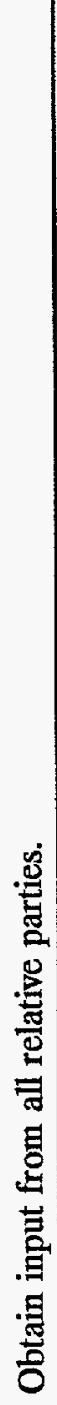 & 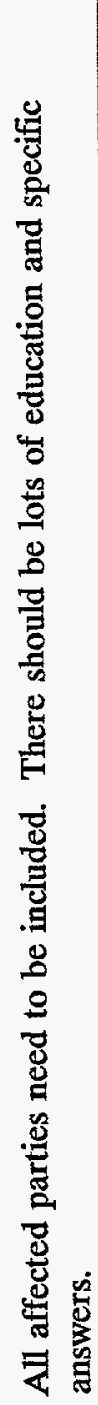 \\
\hline$\frac{5}{3}$ & 焉 & 营 & 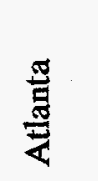 \\
\hline$\frac{\ddot{\pi}}{\tilde{\sigma}}$ & Z & $\stackrel{5}{5}$ & 3 \\
\hline 봉 & $\nabla$ & $\forall$ & $m$ \\
\hline 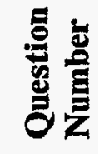 & $a$ & $a$ & $a$ \\
\hline ق & $\vec{m}$ & ले & $m$ \\
\hline
\end{tabular}


Appendix C

\section{Workshop Evaluation Comments}




\section{BUILDING ENERGY CODES AND STANDARDS WORKSHOP - EVALUATION SUMMARY}

June 1-2, 1995. Chicago, IL.

Thirteen Chicago workshop attendees filled out evaluation forms. The following is a summary of their responses.

1. Was the format of this workshop useful and what specific changes would you recommend we make to future workshops?

All thirteen attendees who filled out evaluation forms said that the workshop was useful. Some of these people also gave suggestions for how the workshop might be improved, including:

- $\quad$ Rearrange agenda to have state program examples presented earlier on day 1. Also distribute the technical presentations in with the administrative sessions so things don't get so dry".

- "Hand out copies of implementation materials at the workshop (i.e., MecCheck)".

- "Break presentations into smaller segments with more breaks".

- $\quad$ "Change layout of tables for more informal setting".

- "Shorten to one day".

- "Longer breaks".

- $\quad$ "State presenters should talk about what has actually been done in the state versus what they plan to do".

2. What sessions of the workshop were most useful/informative for you?

Attendees listed their favorite session(s) and provided additional comments.

Number

$1 \quad$ All sessions equally useful

5 Train the Trainer

$5 \quad$ MEC Implementation materials

$4 \quad$ Home Energy Rating Systems

2 ASHRAE overview

$2 \quad$ Direct technical assistance

$2 \quad$ Utility session (IES Utilities)

1 BESP overview

Additional comments:

- "Best sessions were those that cover how, what, where".

- $\quad$ "The best part of the workshop was finding out about support available to my state".

- $\quad$ "It was good to find out the role of BESP and DOE and find out about available resources".

- $\quad$ "All sessions that discussed non-regulatory methods of encouraging energyefficiency were the best".

3. Are there additional topics you would have liked to see covered at the workshop?

Eight of the 13 respondents said that no additional topics needed to be covered. Five had suggestions:

- Major renovations should be addressed.

- State adoption and enforcement of building energy codes.

- Sustaining energy code compliance.

- More information on HERS. 
- Mention the relative potential for conservation for various building components (i.e., improved lighting offers more than improving building insulation).

- How to customize national materials for state/local use.

4. Should we eliminate any sessions from future workshops? Why?

Ten resopndents said that no sessions should be eliminated and three had specific recommendations for revising or eliminating sessions:

- Video - too limited to convince architects.

- DOE promotion of building energy codes.

- DOE grant awards is only useful before grants have been submitted so states have more guideance in submitting an RFP.

- $\quad$ Shorten discussion of EZ Com since nothing is ready yet and the audience is administrative oriented.

- $\quad$ Role of DOE, BESP Overview, Direct TA, BCAP - provide material in advance and give brief overview.

5. What (if any) stakeholder groups (i.e., designers, builders, code officials) do you believe would benefit from a similar workshop?

Some of the respondents said that stakeholders would benefit from similar workshops. Most said the workshop would need to be revised to meet the needs of specific groups typically more technical and hands on. Some said that the best way to reach these groups would be through their national meetings. One respondent from IL said that it would not be valuable to meet with these groups until a code is adopted. Specific stakeholder groups mentioned were code officials (4), builders (1), and designers (1).

6. Were the presenters and facilitators effective and helpful?

All 13 said that the presenters and facilitators were effective and helpful. Specific comments include:

- "They covered a variety of perspectives that our state hadn't had the opportunity to explore".

- $\quad$ "The presenters were well organized and in general did a very good job.

- About $60 \%$ of the presenters were effective".

7. Did this workshop provide opportunities to network? Was this useful?

All respondents said that the workshop was a valuable opportunity for them to network with their peers. The following comments were made:

- $\quad$ "The workshop allowed us to find out who to talk to and how".

- $\quad$ "Need more opportunities during the day rather than the evening".

- "I met many people I have spoken to previously on the phone".

- $\quad$ "I believe our state will obtain information from these people for years".

- "These contacts will be helpful and useful for years to come".

- $\quad$ "It would also be useful to have a list of all energy code writers across the US so we could network with these people too".

8. How often would you like to see a workshop similar to this one held?

When asked how often they would like to see a workshop similar to this one held, all respondents said once per year. 


\section{BUILDING ENERGY CODES AND STANDARDS WORKSHOP - EVALUATION SUMMARY}

June 19-20, 1995, Denver, Colorado

Ten workshop attendees filled out this evaluation form. The following is a summary of their responses.

1. Was the format of this workshop useful and what specific changes would you recommend we make to future workshops?

Nine of the ten attendees who filled out the evaluation form said that the workshop format was useful and had no suggestions for improvement. One attendee said that the format was generally o.k., but many short talks are not useful for a first-time attendee. Another said that the workshop could have used more "focus/purpose/specifics".

2. What sessions of the workshop were most useful/informative for you?

Attendees listed their favorite session(s) and provided additional comments.

Number

7 HERS

6 ASHRAE implementation materials

4 MEC implementation materials

1 State progressive/exemplary programs

1 State technical assistance examples

1 Questions/discussion sessions

3. Are there additional topics you would have liked to see covered at the workshop?

Three of the 10 respondents said that no additional topics needed to be covered. Seven had suggestions:

- "More information on code changes and updates".

- "Information on DOE's role in code implementation and enforcement".

- "Expanded discussion of linking HERS to EEMs"?

- "Hold a session on the concerns and positions of different stakeholder groups (builders, realtors, designers, etc) regarding building energy codes".

- "More detail on MEC development".

- "More information on the DOE grants - who received them, how much, what will the states be doing".

- "More process-oriented program information, such as the best approaches to adoption, implementation, and enforcement, and what hasn't worked as well as what has".

- "A summary of how codes are implemented in the states".

- "A presentation by a builder to address his group's concerns and needs regarding codes".

4. Should we eliminate any sessions from future workshops? Why?

Nine of the ten respondents said that no sessions should be eliminated at future workshops. However one mentioned that speakers should be coached more on what to cover so their time is not exceeded. Another said the state presentations needed to be more focused and answer/address specific questions and needs. One respondent suggested eliminating the utility presentation if it remains unchanged from what was presented because, he believed, it was of little value to the attendees. 
5. What (if any) stakeholder groups (i.e., designers, builders, code officials) do you believe would benefit from a similar workshop?

Specific stakeholder groups mentioned were code officials (2), appraisers (2), builders (1), lenders (2), realtors (2), and "all stakeholders" (2).

6. Were the presenters and facilitators effective and helpful?

All 10 said that the presenters and facilitators were effective and helpful. However one respondent said he had trouble hearing certain presenters, and another said some of the sessions were too lengthy. One respondent commented, "The presentations were good and the facilitator helped keep the workshop moving and on time".

7. Did this workshop provide opportunities to network? Was this useful?

All respondents said that the workshop was a valuable opportunity for them to network with their peers.

8. Ideally, how long would you prefer to spend at the workshop?

a. A half day

b. 3 One day

c. 6 One and a half days (like this workshop)

d. Two days

e. - More than 2 days (specify)

f. - Other (explain)

9. How often would you like to see a workshop similar to this one held?

a. 1 Once every six months

b. 5 Once per year

c. 1 Once every 18 months

d. 1 Once every 2 years

e.__ Other (explain) 


\section{BUILDING ENERGY CODES AND STANDARDS WORKSHOP - EVALUATION SUMMARY}

June 22-23, 1995, Lincoln, Rhode Island

Eleven workshop attendees filled out this evaluation form. The following is a summary of their responses.

1. Was the format of this workshop useful and what specific changes would you recommend we make to future workshops?

Eight of the eleven attendees who filled out the evaluation form said that the workshop format was useful and had no suggestions for improvement. Specific comments include:

- "I found that the format was very useful. Scheduling a loose program of presentations led to conversations and ideas into specific areas of concern and interest, with time left for discussion".

- "The information presented addressed large general areas".

Three of the workshop attendees had suggestions for how the workshop format could be improved:

- "The format was not very useful for my needs, but it did give me an idea of what government is willing to do to promote energy conservation.

- "Small roundtable discussions with states would be very useful. Maybe one for residential and one for commercial".

- "Softer chairs - seat cushions".

2. What sessions of the workshop were most useful/informative for you?

Attendees listed their favorite session(s) and provided additional comments.

Number

8 ASHRAE implementation materials

5 MEC implementation materials

2 Oregon exemplary program discussion

1 HERS

1 Utility DSM programs

1 Questions/discussion sessions

3. Are there additional topics you would have liked to see covered at the workshop?

Six of the 11 respondents said that no additional topics needed to be covered. Four had suggestions:

- "Spend more time on the interaction between HERS and codes".

- "Provide an overview of the best available materials, methods, and tools that can be used to facilitate code compliance".

- "Discussion about how 90.1 was upgraded and the specific areas that were changed. Also explain how the changes were justified - economics, performance, experience"?

- "Provide a longer discussion of experiences of states who are far ahead - like Oregon".

4. Should we eliminate any sessions from future workshops? Why?

Ten resopndents said that no sessions should be eliminated. One respondent said that the utility session was not very useful to him, although he did agree that the linkage between codes and DSM programs is important. 
5. What (if any) stakeholder groups (i.e., designers, builders, code officials) do you believe would benefit from a similar workshop?

Specific stakeholder groups mentioned were code officials (4), designers (4), builders (3), engineers (3), and material suppliers (1).

6. Were the presenters and facilitators effective and helpful?

All 11 said that the presenters and facilitators were effective and helpful. Specific comments include:

- "Absolutely, very professional and thorough".

- "They were very informed on their respective subjects".

- "They were all very effective and helpful".

7. Did this workshop provide opportunities to network? Was this useful?

All respondents said that the workshop was a valuable opportunity for them to network with their peers.

8. Ideally, how long would you prefer to spend at the workshop?
a. A half day
b. 1 One day
c. $\frac{1}{8}$ One and a half days (like this workshop)
d. 2 Two days
e. - More than 2 days (specify)
f.__ Other (explain)

10. How often would you like to see a workshop similar to this one held?
a. 1 Once every six months
b. 8 Once per year
c. 1 Once every 18 months
d. 1 Once every 2 years
e. Other (explain) 
WORKSHOP EVALUATION FORM SUMMARY

June 27-28, 1995, Atlanta, Georgia

Fifteen workshop attendees filled out the evaluation form. The following is a summary of their responses.

1. Was the format of this workshop useful and what specific changes would you recommend we make to future workshops?

Respondents reported that the workshop was useful. Specific comments include:

- Appreciated flexibility.

- Be sure that all handouts are in the workbook.

- More time to explore ideas.

2. What sessions of the workshop were most useful/informative for you?

Respondents listed their favorite session(s) and provided additional comments.

Number

$\begin{array}{ll}7 & \text { MEC Implementation materials } \\ 6 & \text { Utility discussion with Florida Power \& Light } \\ 4 & \text { ASHRAE overview } \\ 3 & \text { What other states are doing } \\ 3 & \text { All sessions equally useful } \\ 2 & \text { Home Energy Rating Systems } \\ 1 & \text { Technical assistance available } \\ 1 & \text { Input on model codes }\end{array}$

3. Are there additional topics you would have liked to see covered at the workshop?

Eight of the 13 respondents said that no additional topics needed to be covered. Others had specific suggestions:

- Focus on code compliance issues.

- More detail on ASHRAE 90.1.

- More time on HERS and how a state qualifies for an EEM.

- Information on building orientations to minimize east/west orientation.

- Session on perspectives of architects. They set up building parameters and by the time engineers get the job all the money is spent in embellishments with little left for HVAC equipment/electric equipment/plumbing.

- Would like to see ASHRAE represented at the workshop.

- Discussion on how to integrate alternative energy sources.

- Would like to see a broader range of states represented with an emphasis on states in transition. Also from states where the energy office doesn't have prime responsibility for codes.

- How DOE and PNL are working with model code groups to bring codes in line with EPAct standards.

- More on air infiltration.

4. Should we eliminate any sessions from future workshops? Why?

Eleven respondents said that no sessions should be eliminated. Others had specific recommendations for revising or eliminating sessions:

- Less detail on funding process.

- Less DOE administrative information.

- Eliminate the power company presentations. 
- Eliminate ALL programs except MEC implementation materials.

5. What (if any) stakeholder groups (i.e., designers, builders, code officials) do you believe would benefit from a similar workshop?

Some of the respondents reported that stakeholders would benefit from similar workshops. Four respondents reported that all stakeholders would benefit from similar workshops. Others mentioned specific stakeholder groups, including code officials (5), builders (5), designers (4), developers (1), engineers (1), subcontractors (1), material suppliers (1), and utility representatives (1).

6. Were the presenters and facilitators effective and helpful?

Fourteen respondents reported that the presenters and facilitators were effective and helpful. However one respondent suggested having the technicians who work on the program deliver the sessions, versus "salesman".

7. Did this workshop provide opportunities to network? Was this useful? Respondents reported that the workshop provided opportunities to network, which was useful. One respondent reported, "It is always useful to talk to others to determine their success/efforts and how we could possibly implement these." Another reported that, while the workshops were useful in terms of networking, there should have been more emphasis on it by allowing groups to form to discuss topics. Another said even more time could have been devoted to networking.

8. Ideally, how long would you prefer to spend at the workshop?

a. A half day

b. 1 One day

c. 8 One and a half days (like this workshop)

d. 5 Two days

e. More than 2 days (specify)

f. 1 Other (explain) 2 short davs, sav 6 hours each.

9. How often would you like to see a workshop similar to this one held?

a. 3 Once every six months

b. 10 Once per year

c. Once every 18 months

d. Once every 2 years

e. 2 Other (explain) 1) as code changes or other happenings occur. 